\title{
Synthesis of Fused Dihydroazepine Derivatives of Fullerenes by a Rh-Catalyzed Cascade Process
}

\author{
Albert Artigas, ${ }^{+a}$ Cristina Castanyer, ${ }^{+a}$ Nil Roig, ${ }^{\text {a }}$ Agustí Lledó, ${ }^{a}$ Miquel Solà, \\ Anna Pla-Quintana, ${ }^{\mathrm{a}, *}$ and Anna Roglans ${ }^{\mathrm{a}, *}$ \\ a Institut de Química Computacional i Catàlisi (IQCC) and Departament de Química, Universitat de Girona (UdG), Facultat de \\ Ciències, C/Maria Aurèlia Capmany, 69, 17003-Girona, Catalunya, Spain \\ E-mail: anna.plaq@udg.edu; anna.roglans@udg.edu
}

These authors contributed equally.

Manuscript received: May 26, 2021; Revised manuscript received: June 16, 2021;

Version of record online: June 29, 2021

Supporting information for this article is available on the WWW under https://doi.org/10.1002/adsc.202100644

의 (C) 2021 The Authors. Advanced Synthesis \& Catalysis published by Wiley-VCH GmbH. This is an open access article under the terms of the Creative Commons Attribution Non-Commercial NoDerivs License, which permits use and distribution in any medium, provided the original work is properly cited, the use is non-commercial and no modifications or adaptations are made.

Abstract: A synthetic methodology is reported that functionalizes $\mathrm{C}_{60}$ and $\mathrm{C}_{70}$ fullerenes with dihydroazepine rings by a cascade reaction encompassing a rhodium-catalyzed cycloisomerization of 1,5-bisallenes and a [4+ 2] cycloaddition. This transition metal-catalyzed cascade reaction provides a versatile and step-economical approach to the synthesis of 6,7-membered polyheterocyclic fullerene adducts. Electrochemical characterization of the products obtained ventures their application in organic and perovskite photovoltaic devices.

Keywords: Cycloaddition; Density Functional Calculations; Fullerenes; Rhodium; Solar Cells

\section{Introduction}

The functionalization of fullerenes represents one of the most powerful approaches towards the development of novel carbon nanomaterials. ${ }^{[1]}$ Exohedrally modified fullerenes with enhanced physicochemical, electrochemical or photophysical properties are promising functional molecules with potential use in a variety of fields, ranging from biomedicine ${ }^{[2-4]}$ to nextgeneration photovoltaics. $^{[5-9]}$

In the thirty years since $\mathrm{C}_{60}$ was obtained in macroscopic quantities for the first time, ${ }^{[10]}$ synthetic organic chemists have come up with countless methodologies to functionalize fullerenes. ${ }^{[11]}$ In this regard, the double bonds found at the junctions between the sixmembered rings of fullerene cages -the so-called $[6,6]$ bonds - participate effectively in numerous chemical reactions, of which cyclopropanations ${ }^{[12-14]}$ and 1,3dipolar cycloadditions ${ }^{[15-17]}$ are amongst the most commonly used. The electron-deficient nature of $\mathrm{C}_{60}$, $\mathrm{C}_{70}$, and higher fullerenes also makes $[6,6]$ bonds excellent dienophiles in Diels-Alder (DA) cycloadditions. ${ }^{[18-20]}$ Functionalization of fullerenes by DA reactions has been used with great success in the field of materials science. In this sense, fullerene adducts obtained through DA reactions with indene (e.g. $\mathrm{IC}_{60} \mathrm{BA}^{[21]}$ and $\mathrm{IC}_{70} \mathrm{BA}^{[22]}$ ) constitute some of the state-of-the-art n-type semiconductor materials in organic and perovskite photovoltaics. ${ }^{[1]}$

On the other hand, transition metal-mediated annulation reactions have considerably enriched the synthetic toolbox available for fullerene functionalization. In fact, radical reactions mediated by transition metal salts dominate the field. ${ }^{[23]}$ However, other methodologies, including $\mathrm{C}-\mathrm{H} / \mathrm{C}-\mathrm{X}$ functionalization $^{[24]}$ or $[2+2+2]$ cycloadditions ${ }^{[25-28]}$ have been reported as well. A complementary yet convenient approach relies on the in situ generation of reactive intermediates, such as 1,3-dienes, by the participation of transition metal complexes or transition metal salts, followed by reaction with the fullerene (Scheme 1). ${ }^{[29-32]}$ Such cascade reactions offer molecular complexity from simple structures. 


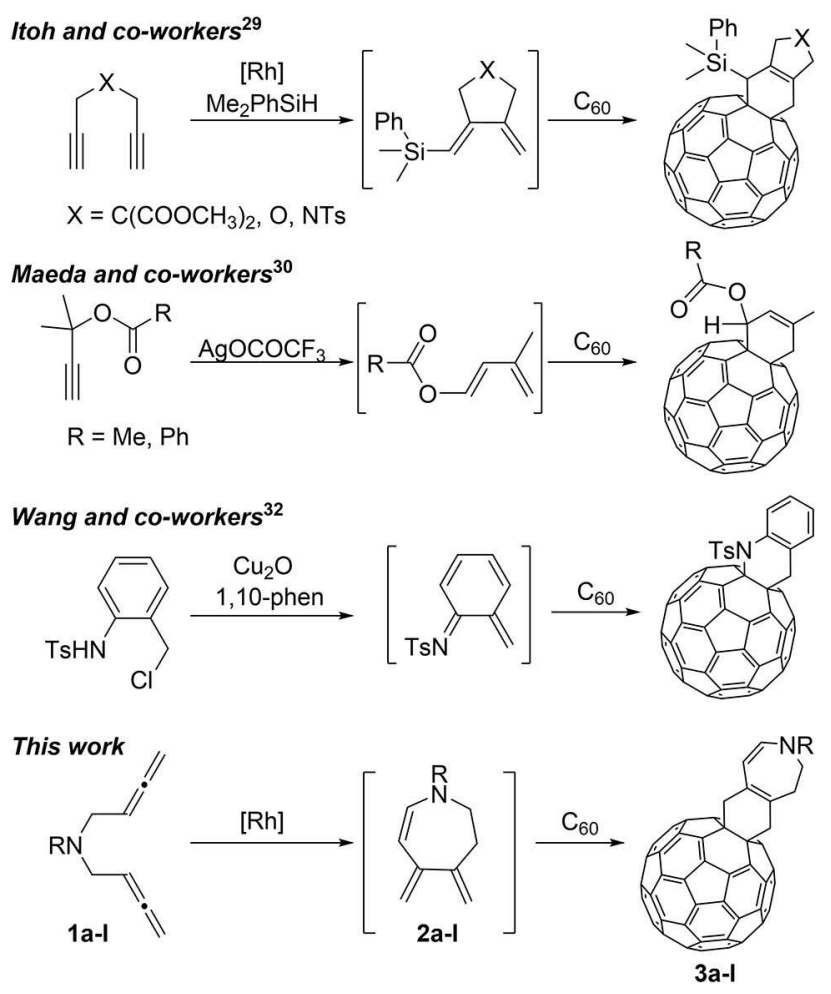

Scheme 1. Cascade reactions of $\mathrm{C}_{60}$ with in situ generated 1,3dienes.

When treated under transition metal-catalysis, 1,5bisallenes cycloisomerize to provide a wide variety of carbo- and heterocyclic compounds bearing 4-, 5-, 6and 7-membered rings. ${ }^{[33-39]}$ We have recently shown that 1,5-bisallenes $\mathbf{1}$ can be selectively transformed into their corresponding 7-membered cycloisomers $\mathbf{2}$, which contain an exocyclic 1,3-diene, in the presence of cationic $\mathrm{Rh}^{\mathrm{I}}$-diphosphine catalysts (see Scheme 1). These promiscuous intermediates readily react with a dienophile present in the reaction mixture, providing fused dihydroazepine polycyclic systems. ${ }^{[40]}$ Given that fullerene adducts containing 7-membered rings are scarce and challenging to prepare, ${ }^{[41-47]}$ and azepane based compounds showed a variety of pharmacological properties ${ }^{[48]}$ we envisaged a synthetic protocol to prepare structurally appealing fused dihydroazepine derivatives of $\mathrm{C}_{60}$ and $\mathrm{C}_{70}$ by in situ generation of the 1,3-diene (Scheme 1).

\section{Results and Discussion}

We initiated our investigations by studying the reaction conditions for the cycloaddition reaction between fullerene $\mathrm{C}_{60}$ and $\mathrm{N}$-tosyl-tethered bisallene $\mathbf{1}$ a (see Table 1 and Table S1 in the Supporting Information). In our first attempts, an equimolar mixture of a cationic rhodium complex $\left[\mathrm{Rh}(\operatorname{cod})_{2}\right] \mathrm{BF}_{4} \quad(\operatorname{cod}=$ cyclooctadiene) and (R)-DTBM-seghpos, pre-treated under

Table 1. Optimization of the rhodium(I)-catalyzed cycloaddition of bisallene $\mathbf{1}$ a with fullerene $\mathrm{C}_{60} \cdot{ }^{[\mathrm{a}]}$

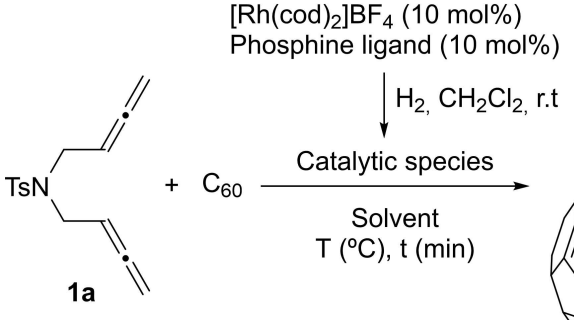

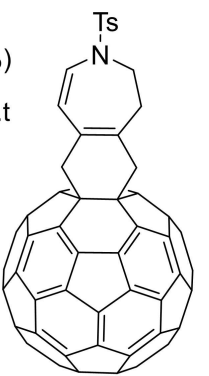

3a

\begin{tabular}{|c|c|c|c|c|c|}
\hline Entry & Ligand & $\begin{array}{l}\text { Ratio } \\
\mathrm{C}_{60}: \mathbf{1} \mathbf{a}\end{array}$ & $\begin{array}{l}\text { Solvent/T } \\
\left({ }^{\circ} \mathrm{C}\right)\end{array}$ & $\begin{array}{l}\mathrm{T} \\
(\min )\end{array}$ & $\begin{array}{l}\text { Yield } \\
(\%)\end{array}$ \\
\hline 1 & $\begin{array}{l}(R) \text {-DTBM- } \\
\text { segphos }\end{array}$ & $1: 2$ & $o-\mathrm{DCB} / 180$ & 30 & 0 \\
\hline 2 & $\begin{array}{l}(R) \text {-DTBM- } \\
\text { segphos }\end{array}$ & $1.1: 1$ & $o-\mathrm{DCB} / 180$ & 15 & $<5$ \\
\hline 3 & $\begin{array}{l}(R) \text {-DTBM- } \\
\text { segphos }\end{array}$ & $1.1: 1$ & $o-\mathrm{DCB} / 120$ & 15 & $<5$ \\
\hline 4 & $\begin{array}{l}(R) \text {-DTBM- } \\
\text { segphos }\end{array}$ & 1.1:1 & $o-\mathrm{DCB} / 90$ & 20 & 56 \\
\hline 5 & $\begin{array}{l}(R) \text {-DTBM- } \\
\text { segphos }\end{array}$ & $1.1: 1$ & Toluene/60 & 30 & 0 \\
\hline 6 & $(R)$-BINAP & $1.1: 1$ & $o-\mathrm{DCB} / 90$ & 240 & 42 \\
\hline 7 & $\begin{array}{l}(R)-\mathrm{H}_{8}-\mathrm{BI}- \\
\text { NAP }\end{array}$ & 1.1:1 & $o-\mathrm{DCB} / 90$ & 240 & 42 \\
\hline 8 & $\begin{array}{l}(R) \text {-Tol-BI- } \\
\text { NAP }\end{array}$ & $1.1: 1$ & $o-\mathrm{DCB} / 90$ & 240 & 20 \\
\hline
\end{tabular}

${ }^{\text {[a] }}$ Reaction conditions: $0.06 \mathrm{mmol}$ of $1 \mathrm{a}, 10 \mathrm{~mol} \%$ of $\mathrm{Rh}$ catalyst in $o$-DCB $(1.4 \mathrm{mM})$ at the indicated temperature and time. The $10 \mathrm{~mol} \%$ mixture of $\left[\mathrm{Rh}(\mathrm{cod})_{2}\right] \mathrm{BF}_{4}$ and phosphine ligand was treated with hydrogen in dichloromethane $\left(\mathrm{CH}_{2} \mathrm{Cl}_{2}\right)$ solution for catalyst activation prior to substrate addition.

hydrogenation conditions, was used as a catalyst. Upon heating the reaction mixture for $30 \mathrm{~min}$ in refluxing $o$ dichlorobenzene $(o-\mathrm{DCB})$ and using an excess of bisallene 1 a ( 2 equivalents, with respect to $\mathrm{C}_{60}$ ), we did not observe the formation of the desired product 3 a. However, no starting materials were recovered (entry 1, Table 1). Conversely, complete retention at the bottom of the TLC plate was observed. This suggested that an excess of bisallene in the reaction mixture may promote polyaddition. Given this, we attempted the reaction using only a slight excess of $\mathrm{C}_{60}$ (1.1 equivalents) and reducing the reaction time to 15 min (entry 2, Table 1). After subjecting the reaction crude directly to column chromatography, we managed to isolate a small amount of a reaction product, which eluted as a brown band following unreacted $\mathrm{C}_{60}$. We then proceeded to analyze the effect of the temperature. We first performed the reaction at $120^{\circ} \mathrm{C}$ but did not observe any improvement in the yield (entry 3, 
Table 1). Further lowering the temperature to $90{ }^{\circ} \mathrm{C}$ and carefully monitoring the reaction progress by TLC allowed us to obtain the desired product in a $56 \%$ isolated yield after only 20 minutes of reaction (entry 4, Table 1). Further optimization of the reaction conditions was attempted by changing the solvent to toluene and lowering the temperature to $60{ }^{\circ} \mathrm{C}$ (entry 5 , Table 1). However, no reactivity was observed in this case. We then turned our attention to other diphosphine ligands (entries 6-8, Table 1). All of these turned out to be less effective, requiring longer reaction times and providing lower yields of the desired cycloadduct. Finally, we attempted to reduce the catalyst load, but employing $5 \mathrm{~mol} \%$ of cationic rhodium/diphosphine mixture was detrimental in terms of reaction yield.

We then proceeded to fully characterize the product formed. The molecular formula of the new compound was determined to be $\mathrm{C}_{75} \mathrm{H}_{17} \mathrm{NO}_{2} \mathrm{~S}$ by ESI-HRMS, indicating the formation of a monoadduct. The ${ }^{13} \mathrm{C}$ NMR spectra exhibited only 35 peaks of the 38 expected (30 from the fullerene core, 4 from the tosyl group and 4 corresponding to the $s p^{2} \mathrm{C}$ atoms of the addend) in the range of $110-160 \mathrm{ppm}$ due to some overlapping, and 7 signals in the $s p^{3}$ region. The ${ }^{1} \mathrm{H}$ NMR spectrum displayed characteristic doublets corresponding to the olefinic protons $(\delta=5.57 \mathrm{ppm}$ and $6.97 \mathrm{ppm}$ ) and three signals corresponding to methylene groups $(\delta=2.86 \mathrm{ppm}, 3.97 \mathrm{ppm}$ and $4.04 \mathrm{ppm})$. The absorption spectrum showed an absorption band at $435 \mathrm{~nm}$, which is in accordance with the characteristic pattern expected for a $\mathrm{C}_{60}$ monoadduct. ${ }^{[49]}$ Taken together, all these data allowed us to unambiguously identify the product formed as $\mathbf{3} \mathbf{a}$.

It is worth noting that although $\mathbf{3} \mathbf{a}$ is particularly sensitive to room light and atmospheric air exposure, pure samples could be obtained and fully characterized. To further understand the reactivity of $\mathbf{3}$ a towards light and oxygen, a $\mathrm{CHCl}_{3}$ solution of $\mathbf{3} \mathbf{a}$ was stirred under air and light exposure. After 16 hours, TLC monitoring revealed the complete consumption of $\mathbf{3} \mathbf{a}$, along with the appearance of a new significantly more retained brown spot $\left(\mathrm{R}_{f}=0.27\right.$; toluene). ESI-HRMS analysis of this solution clearly showed a major peak corresponding to $\left[\mathrm{M}(3 \mathbf{a})+\mathrm{O}_{2}+\mathrm{Na}\right]^{+}$(See Figure $\mathrm{S} 1$ in the Supporting Information). Unfortunately, purification by column chromatography and ${ }^{1} \mathrm{H}$ NMR analysis did not allow the identification of a defined oxidation product. Conversely, a complex spectrum, representative of a complex mixture of products, was observed. Based on this, we hypothesized that a nonspecific reaction of $\mathbf{3}$ a with singlet oxygen $\left({ }^{1} \mathrm{O}_{2}\right)$ might have been operative. Such events have been extensively reported in the literature. ${ }^{[28,50-57]}$ In fact, the outstanding affinity of fullerenes and fullerene derivatives for free radicals has been exploited in medicinal chemistry as an approach to treat oxidative stress. ${ }^{[58]}$
Cycloadduct $\mathbf{3} \mathbf{a}$ is expected to form via a DA reaction of $\mathrm{C}_{60}$ with cycloheptatriene intermediate $\mathbf{2}$ a (that is formed through a $\mathrm{Rh}(\mathrm{I})$ catalyzed cycloisomerization as has been studied by us previously $\left.{ }^{[40]}\right)$. To corroborate this hypothesis, we computed the Gibbs energy profile of the DA reaction between $\mathbf{2} \mathbf{a}$ and $\mathrm{C}_{60}$ at the M06-2X-D3/cc-pVTZ(SMD $=o-\mathrm{DCB}) / / \mathrm{B} 3 \mathrm{LYP}-$ D3/cc-pVDZ level of theory (Figure 1, see SI for a more detailed description of the computational method used). ${ }^{[59]}$ According to our computational study, the reaction was found to be exergonic by $11.8 \mathrm{kcal} / \mathrm{mol}$, with an activation energy of $27.0 \mathrm{kcal} / \mathrm{mol}$.

With an optimized set of conditions at hand and having established a reaction mechanism, the scope of the reaction was examined, as shown in Figure 2. First, the nature of the substituents at the phenyl ring of the sulfonamide tether in bisallene $\mathbf{1}$ a was explored. The corresponding cycloadducts $\mathbf{3} \mathbf{b}-\mathbf{h}$ were efficiently obtained, indicating that the reaction proceeds well with both electron-donating and electron-withdrawing groups. However, better yields were achieved with electron-donating substituents. Substitution at the ortho position of the phenyl ring (3f) did not hamper the reaction. To extend our methodology to heteroaromatic sulfonamide-tethered 1,5-bisallenes, we performed the reaction with $\mathbf{1} \mathbf{i}$ and $\mathbf{1} \mathbf{j}$. The corresponding $\mathrm{C}_{60}$ adducts $\mathbf{3} \mathbf{i}$ and $\mathbf{3} \mathbf{j}$ were obtained in $43 \%$ and $53 \%$ yields, respectively. Sulfonamide-tethered reaction products bearing aliphatic substituents $(\mathbf{3} \mathbf{k}-\mathbf{l})$ could be synthesized as well with good yields.

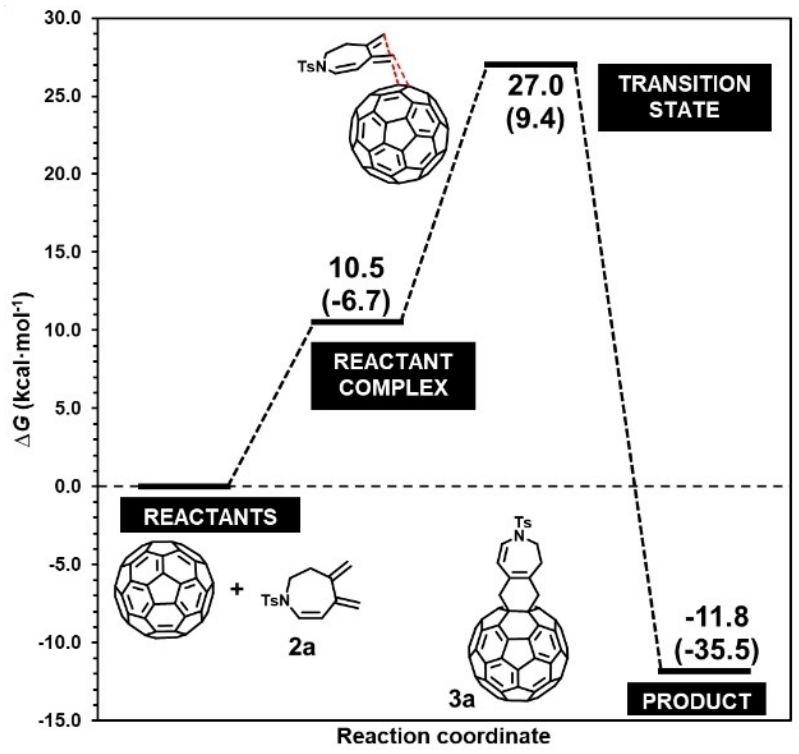

Figure 1. M06-2X-D3/cc-pVTZ(SMD $=o-\mathrm{DCB}) / / \mathrm{B} 3 \mathrm{LYP}-\mathrm{D} 3 /$ cc-pVDZ Gibbs energy profile computed at $363.15 \mathrm{~K}$ of the DA reaction involving fullerene $\mathrm{C}_{60}$ and triene $\mathbf{2} \mathbf{a}$. Values in parentheses correspond to electronic energies $(\Delta E)$. 


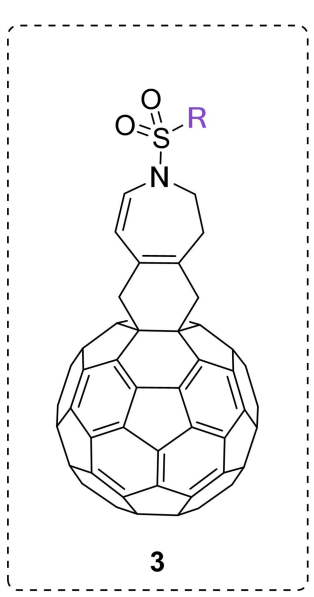

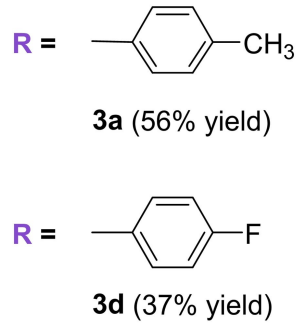

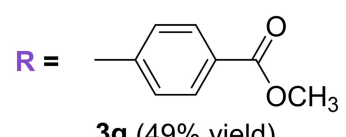

$3 g$ ( $49 \%$ yield)

$\mathrm{R}=$

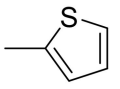

$3 \mathbf{j}(53 \%$ yield)

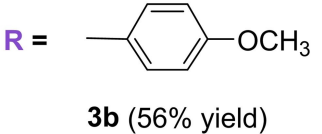

$\mathbf{R}=$

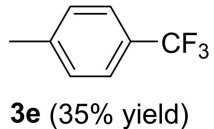

$\mathbf{R}=$<smiles>Cc1ccc([N+](=O)[O-])cc1</smiles>

$3 \mathrm{~h}$ (36\% yield)

$\mathrm{R}=$

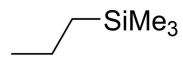

3k (33\% yield)
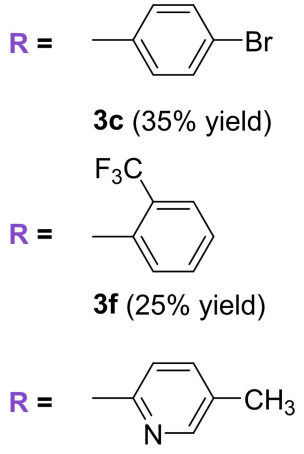

$3 \mathbf{i}(43 \%$ yield)

$R=-f$

$3 \mathbf{l}(36 \%$ yield $)$

Figure 2. Scope of the cycloaddition of $N$-tethered bisallenes $\mathbf{1}$ a-1 l with $\mathrm{C}_{60}$.

We then proceeded to see if 1,5-bisallenes with a tether different from nitrogen were also efficient in the reaction. When the reaction was set up with oxygen tethered 1,5-bisallene no hint of functionalized fullerene could be detected. Conversely, carbon tethered bisallenes efficiently participated in the cascade functionalization (Figure 3). Diethyl malonate as a tethering unit in the bisallene (1 $\mathbf{~ m})$ was initially tested providing a $27 \%$ yield of the carbocyclic analogue $\mathbf{3} \mathbf{~ m}$. Methyl 2-phenylacetate tethered 1,5-bisallene (1 n) was also tested affording a $32 \%$ yield of the functionalized fullerene $\mathbf{3 n}$. When the carboalkoxy group in bisallene $\mathbf{1} \mathbf{n}$ was replaced by a sulfo group $(\mathbf{1 0})$, the reaction afforded a $39 \%$ of the functionalized fullerene 3o. Finally, bisallene $\mathbf{1 p}$ also participated in the reaction to afford $\mathbf{3} \mathbf{p}$. It is to be noted that bisallenes $1 \mathbf{n}, 1 \mathbf{o}$ and $1 \mathbf{p}$ reacted markedly slower than the $N$ tethered bisallenes requiring $2 \mathrm{~h}$ of reaction time.

Next, we attempted the reaction with $\mathrm{C}_{70}$ fullerene (Scheme 2). ESI-HRMS indicated again the formation

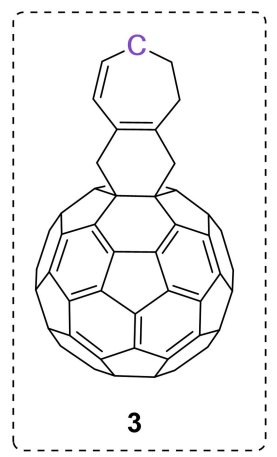<smiles>C=CC(=O)OCC</smiles><smiles>COC(=O)C=Cc1ccccc1</smiles>

$3 m(27 \%$ yield $)$ $3 n(32 \%$ yield $)$

$$
\mathrm{C}=\overbrace{\mathrm{Ph}}
$$

of a monoadduct. However, careful analysis of 2D NMR spectra and HPLC chromatograms evidenced that a mixture of regioisomers with two major products in a 3:1 ratio had been formed (See Figures S2 in the Supporting Information).

UV-Vis experiments evidenced the formation of an $\boldsymbol{\alpha}$ adduct as the major reaction product, but the different regioisomers formed could not be separated. Plausible structures for the observed cycloadducts are: two $\boldsymbol{\alpha}$ isomers ( $\boldsymbol{\alpha}-\mathbf{4 a}$ and $\boldsymbol{\alpha}-\mathbf{4 a}$ ') differing in the approximation of $\mathbf{2} \mathbf{a}$, which is not symmetric, to the same $\boldsymbol{\alpha}$ bond of $\mathrm{C}_{70}$ and a site-isomer $(\boldsymbol{\beta}-\mathbf{4} \mathbf{a})$ in which 2 a has reacted to a $\boldsymbol{\beta}-\mathrm{C}_{70}$ bond. ${ }^{[60-63]}$ To ascertain the structure of the products detected, we first computed the Gibbs energy profile for the formation of the three different DA adducts (Figure 4). Computations support the selective formation of one out of the two possible $\boldsymbol{\alpha}$-isomers as the major reaction product (blue path in Figure 4), which is clearly favored both kinetically and thermodynamically. The second most favored reaction product would be $\boldsymbol{\beta}-\mathbf{4}$ a according to our computational study (purple path in Figure 4). To better understand the selective formation of $\boldsymbol{\alpha}-\mathbf{4} \mathbf{a}$ over $\boldsymbol{\alpha}-\mathbf{4 a}$ ' we analyzed the approximation of $\mathbf{2} \mathbf{a}$ to $\mathrm{C}_{70}$ on the basis of the Activation Strain Model (ASM) (Figure 4b). ${ }^{[64]}$ The results clearly show that the lower energy of the transition state (TS) leading to product $\boldsymbol{\alpha}-\mathbf{4} \mathbf{a}$ arises from its stabilizing interaction energy along the intrinsic reaction coordinate (IRC), which in turn could be attributed to favorable secondary orbital interactions. ${ }^{[65-68]}$

In an attempt to gather more information on the structure of the cycloadducts, we employed an indirect method to assess the regiochemistry of the reaction depicted in Scheme 2. We looked for a method that could selectively reduce the double bond vicinal to the sulfonamide group. The symmetry of the product 


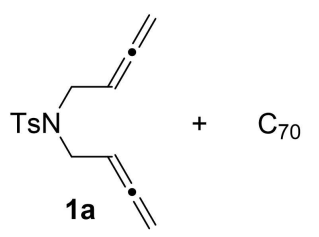

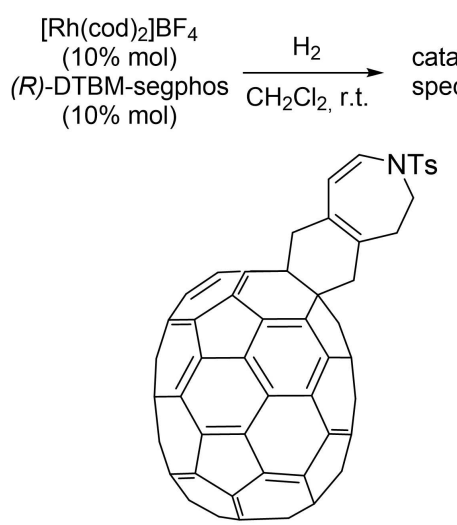

$\alpha-4 a$

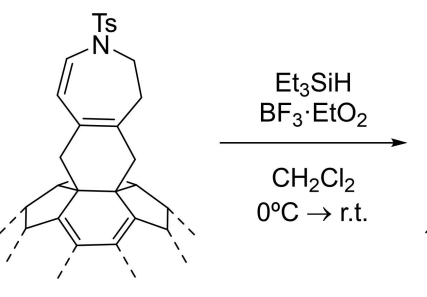

$\mathrm{C}_{60}, 3 \mathrm{a}$

$C_{70}, \alpha-4 a: \beta-4 a(3: 1)$

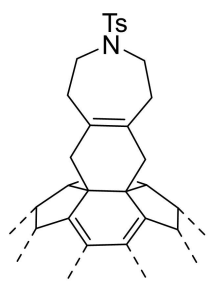

$\mathrm{C}_{60}, 5 \mathrm{a}(82 \%$ yield $)$

$C_{70}, \alpha-6 a: \beta-6 a(3: 1,69 \%$ yield)
Scheme 3. Selective reduction of $\mathbf{3 a}$ and $\mathbf{4 a}$.

from $0{ }^{\circ} \mathrm{C}$ to room temperature ${ }^{[69]}$ provided $\mathbf{5} \mathbf{a}$ in a $82 \%$ yield, which was unambiguously characterized by ESI-HRMS, UV-Vis and NMR experiments.

The same reaction protocol was then applied to the corresponding isomeric mixture of $\mathrm{C}_{70}$ adducts. Selective reduction of the double bond vicinal to the sulfonamide groups in $\boldsymbol{\alpha}-\mathbf{4} \mathbf{a}$ and $\boldsymbol{\alpha}-\mathbf{4 a}$ ' would lead to a single product, as a consequence of the addend's symmetrization. Careful analysis of 2D NMR spectra of the mixture of reduced cycloadducts showed the presence of two major products in a 3:1 molar ratio. Thus, the major one was assigned as $\boldsymbol{\alpha - 6} \mathbf{6} \mathbf{a}$, obtained upon reduction of $\alpha-\mathbf{4} a$ and eventually minor quantities of $\boldsymbol{\alpha}-\mathbf{4 a}$, and the minor one, which showed $C_{\mathrm{s}}$ symmetry and diastereotopic protons, was assigned as $\boldsymbol{\beta}-\mathbf{6} \mathbf{a}$, obtained by reduction of $\boldsymbol{\beta}-\mathbf{4} \mathbf{a}$. Thus, reduction of the enamine bond indirectly confirmed the formation of $\boldsymbol{\alpha}-\mathbf{4} \mathbf{a}$ and $\boldsymbol{\beta}-\mathbf{4} \mathbf{a}$, as main products in the first optimized for $\mathrm{C}_{60}$ adduct $\mathbf{3}$ a (Scheme $3, \mathrm{C}_{60}$ ). Treatment of the exohedrally modified $\mathrm{C}_{60}$ with an excess of $\mathrm{Et}_{3} \mathrm{SiH}$ and $\mathrm{BF}_{3} \cdot \mathrm{Et}_{2} \mathrm{O}$ in $\mathrm{CH}_{2} \mathrm{Cl}_{2}$ solution
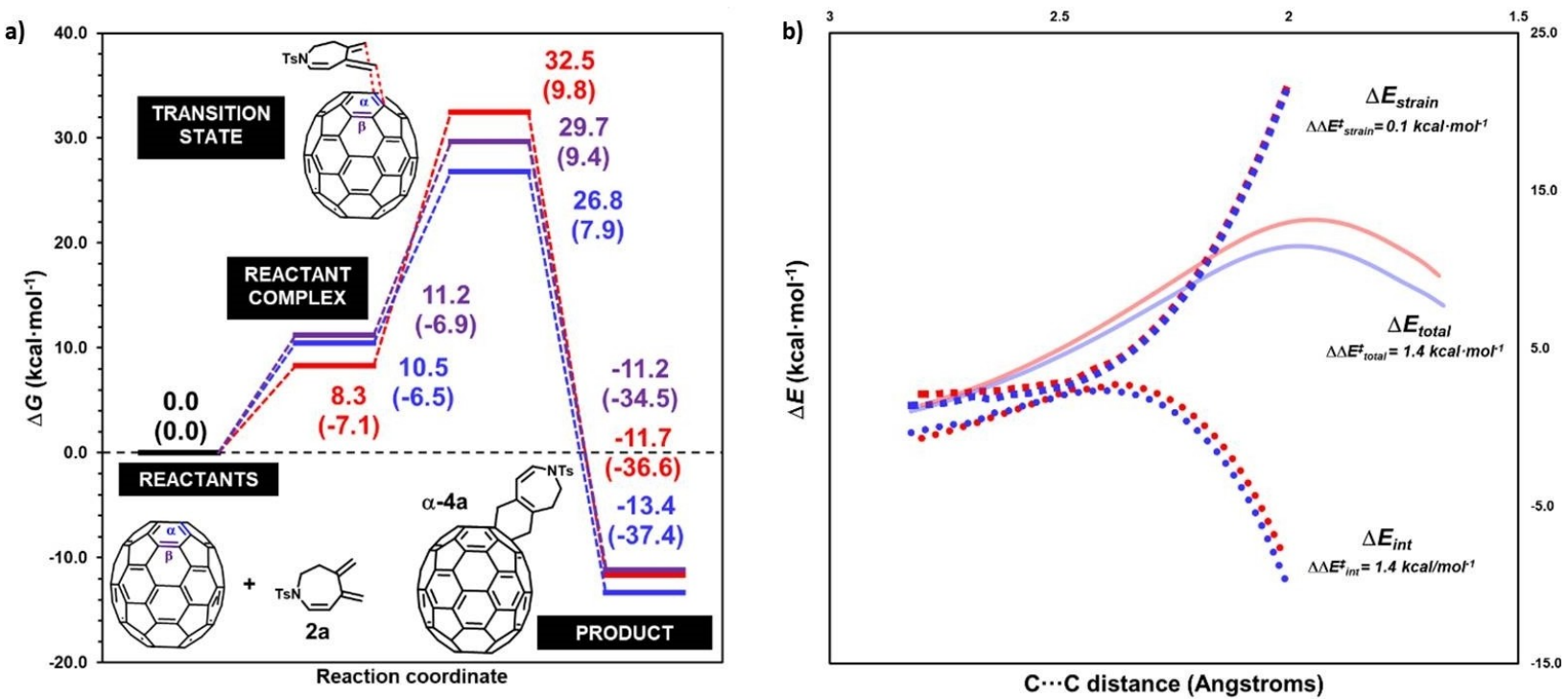

Figure 4. (a) M06-2X-D3/cc-pVTZ(SMD =o-DCB)//B3LYP-D3/cc-pVDZ Gibbs energy profile computed at $363.15 \mathrm{~K}$ of the DA reaction involving fullerene $\mathrm{C}_{70}$ and triene $\mathbf{2}$ a (blue and red paths: two different orientations of $\alpha$ bond; purple path: $\beta$ bond). Values in parentheses are electronic energies $(\Delta E)$. (b) M06-2X-D3/cc-pVTZ(SMD $=o$-DCB) //B3LYP-D3/cc-pVDZ total energy $\left(\Delta E_{\text {total }}\right)$ along the IRC of $\boldsymbol{\alpha}-\mathbf{4} \mathbf{a}$ and $\boldsymbol{\alpha}-\mathbf{4} \mathbf{a}$ ' and their corresponding strain $\left(\Delta E_{\text {strain }}\right)$ and interaction energies $\left(\Delta E_{\text {int }}\right)$ based on the ASM. 
cycloaddition shown in Scheme 2 (as also suggested by the DFT calculations).

Finally, the electrochemical behaviour of compound 3 a was studied by cyclic voltammetry. Under the experimental settings employed, the cycloadduct exhibited two fully reversible reduction waves corresponding to one-electron reductions of the fullerene core. As expected, the reduction potentials of $\mathbf{3} \mathbf{a}$ are negatively shifted compared with those of $\mathrm{C}_{60}$ (see Table 2). The highest occupied molecular orbital/lowest unoccupied molecular orbital (HOMO/LUMO) values were estimated from the ultraviolet (UV) and CV measurements (Table 3). ${ }^{[9,70]}$ The remarkable cathodic shift of the cycloadduct and its excellent alignment with perovskite bands ventures their potential application as n-type materials in organic and hybrid photovoltaic devices.

\section{Conclusion}

In conclusion, we have developed a method to synthesize a series of fullerene adducts bearing 6,7membered polyheterocyclic addends. The reaction relies in a cascade composed of the in situ generation of dienes by a selective $\mathrm{Rh}^{\mathrm{I}}$-catalyzed cycloisomerization of 1,5-bisallenes and a DA reaction with $\mathrm{C}_{60}$ or $\mathrm{C}_{70}$. A combined approach involving computation and experiments allowed us to propose the structure for the main two isomers produced upon reaction with fullerene $\mathrm{C}_{70}$. Electrochemical characterization of the NTs dihydroazepine derivative $\mathbf{3}$ a showed two reduction waves with a remarkable cathodic shift as compared to $\mathrm{C}_{60}$ that could permit their application as electrontransporting materials in perovskite solar cells.

Table 2. Redox potentials of $\mathbf{3} \mathbf{a}$ and $\mathrm{C}_{60} \cdot{ }^{[\mathrm{a}]}$

\begin{tabular}{lllll}
\hline Entry & Compound & $\mathrm{E}_{\text {red }}^{1}$ & $\mathrm{E}_{\text {red }}^{2}$ & $\mathrm{E}_{\text {red }}^{3}$ \\
\hline 1 & $\mathrm{C}_{60}$ & -1.13 & -1.52 & -1.98 \\
2 & $\mathbf{3 a}$ & -1.27 & -1.66 & \\
\hline
\end{tabular}

${ }^{[a]} \mathrm{E}_{1 / 2}$ in $\mathrm{V}$ vs.ferrocene/ferrocenium $\left(\mathrm{Fc} / \mathrm{Fc}^{+}\right), 0.2 \mathrm{mM} \mathrm{C}_{60} / \mathbf{3 a}$ and $0.05 \mathrm{M} \mathrm{Bu}_{4} \mathrm{~N}^{+} \mathrm{PF}_{6}{ }^{-}$in $o$-dichlorobenzene, $\mathrm{Ag} / \mathrm{AgNO}_{3}$ reference electrode, $\mathrm{Pt}$ working electrode, $\mathrm{Pt}$ wire auxiliary electrode, scan rate $50 \mathrm{mV} / \mathrm{s}, 25^{\circ} \mathrm{C}$.

Table 3. Optical bandgap, onset reduction, and lowest unoccupied molecular orbital/highest occupied molecular orbital (LUMO/HOMO) energy levels of $\mathbf{3} \mathbf{a}$.

\begin{tabular}{llllll}
\hline Compound & $\begin{array}{l}\lambda_{\max } \\
(\mathrm{nm})\end{array}$ & $\begin{array}{l}\mathrm{E}_{\mathrm{g}} \\
(\mathrm{ev})\end{array}$ & $\begin{array}{l}\mathrm{E}^{\text {on }}{ }_{\text {red }} \\
(\mathrm{V})\end{array}$ & $\begin{array}{l}\text { LUMO } \\
(\mathrm{ev})\end{array}$ & $\begin{array}{l}\text { HOMO } \\
(\mathrm{ev})\end{array}$ \\
\hline $\mathbf{3 a}$ & 719 & 1.72 & -1.15 & -3.65 & -5.37 \\
\hline
\end{tabular}

\section{Experimental Section}

\section{General Procedure for the Synthesis of Fused Dihydroazepine Derivatives of $\mathrm{C}_{60}(\mathrm{3}$ a)}

In a $10 \mathrm{~mL}$ capped vial under a nitrogen inert atmosphere, a solution of $\left[\mathrm{Rh}(\operatorname{cod})_{2}\right] \mathrm{BF}_{4}(2.2 \mathrm{mg}, 0.006 \mathrm{mmol}$, ) and $(R)-$ DTBM-Segphos (7.5 mg, $0.006 \mathrm{mmol}$ ) in anhydrous $\mathrm{CH}_{2} \mathrm{Cl}_{2}$ $(4 \mathrm{~mL})$ was prepared. Hydrogen gas was bubbled into the catalyst solution for $30 \mathrm{~min}$ before it was concentrated to dryness, dissolved in anhydrous $o-\mathrm{DCB}$ and introduced into a solution of $\mathrm{C}_{60}(46.3 \mathrm{mg}, \quad 0.064 \mathrm{mmol})$ and bisallene $\mathbf{1}$ a $(17.0 \mathrm{mg}, 0.061 \mathrm{mmol})$ in anhydrous $o$-DCB $(1.4 \mathrm{mM})$, preheated to $90^{\circ} \mathrm{C}$. The resulting mixture was stirred at $90^{\circ} \mathrm{C}$ for $20 \mathrm{~min}$ (TLC monitoring), allowed to cool down to room temperature, and directly subjected to column chromatography on silica gel using $\mathrm{CS}_{2}$ as the eluent to provide unreacted $\mathrm{C}_{60}$. Further elution with toluene gave compound 3 a (34.1 mg, 56\% yield) as a dark brown solid.

Compound 3 a. ( $34.1 \mathrm{mg}, 56 \%$ yield, dark brown solid). MW $\left(\mathrm{C}_{75} \mathrm{H}_{17} \mathrm{NO}_{2} \mathrm{~S}\right.$ ): $996.03 \mathrm{~g} / \mathrm{mol}$; Rf: 0.75 (toluene); IR (ATR) $v$ $\left(\mathrm{cm}^{-1}\right): 3082,1344,1159 ;{ }^{1} \mathrm{H}$ NMR $\left(400 \mathrm{MHz}, \mathrm{CDCl}_{3}\right) \delta$ (ppm): 2.39 (s, 3H), 2.86 (t, $J=4.6 \mathrm{~Hz}, 2 \mathrm{H}), 3.97(\mathrm{t}, J=4.6 \mathrm{~Hz}$, $2 \mathrm{H}), 3.99-4.12(\mathrm{~m}, 4 \mathrm{H}), 5.57(\mathrm{~d}, J=9.6 \mathrm{~Hz}, 1 \mathrm{H}), 6.97(\mathrm{~d}, J=$ $9.6 \mathrm{~Hz}, 1 \mathrm{H}), 7.35(\mathrm{~d}, J=8.2 \mathrm{~Hz}, 2 \mathrm{H}), 7.78(\mathrm{~d}, J=8.2 \mathrm{~Hz}, 2 \mathrm{H})$; ${ }^{13} \mathrm{C}$ NMR (101 MHz, $\left.\mathrm{CDCl}_{3}\right) \delta(\mathrm{ppm}): 21.83,38.33,46.53$, $47.88,48.45,66.37,66.39,111.15,127.31,127.80,130.27$, $131.51,135.77,135.87,136.04,138.84,140.27,140.32,141.75$, $141.78,142.17,142.23,142.49,142.51,142.78,142.79,143.29$, $144.29,144.84,144.91,145.53,145.62,145.64,145.67,145.86$, $146.42,146.65,146.67,147.79,147.82,156.64,156.71$ (3 signals are not described due to overlapping); UV-vis (toluene) $\lambda_{\max }(\mathrm{nm}): 435,705 ;$ ESI-HRMS $(\mathrm{m} / \mathrm{z})$ calculated for $[\mathrm{M}+$ $\mathrm{Na}]^{+}=1018.0872$; found 1018.0837.

Compound 3 b. ( $33.7 \mathrm{mg}, 56 \%$ yield, dark brown solid). MW $\left(\mathrm{C}_{75} \mathrm{H}_{17} \mathrm{NO}_{3} \mathrm{~S}\right)$ : $1012.03 \mathrm{~g} / \mathrm{mol}$; Rf: 0.5 (toluene); IR (ATR) $v$ $\left(\mathrm{cm}^{-1}\right): 2917,1258,1155,1091 ;{ }^{1} \mathrm{H}$ NMR $\left(400 \mathrm{MHz}, \mathrm{CDCl}_{3}\right) \delta$ (ppm): 2.89 (t, $J=4.6 \mathrm{~Hz}, 2 \mathrm{H}), 3.82(\mathrm{~s}, 3 \mathrm{H}), 3.97(\mathrm{t}, J=4.6 \mathrm{~Hz}$, 2H), 3.99-4.10 (m, 4H), $5.56(\mathrm{~d}, J=9.6 \mathrm{~Hz}, 1 \mathrm{H}), 6.96(\mathrm{~d}, J=$ $9.6 \mathrm{~Hz}, 1 \mathrm{H}), 7.01(\mathrm{~d}, J=9.0 \mathrm{~Hz}, 2 \mathrm{H}), 7.83(\mathrm{~d}, J=9.0 \mathrm{~Hz}, 2 \mathrm{H})$; ${ }^{13} \mathrm{C}$ NMR $\left(101 \mathrm{MHz}, \mathrm{CDCl}_{3}\right) \delta(\mathrm{ppm}): 38.35,46.52,47.88$, $48.47,55.75,66.38,66.42,111.13,114.78,127.83,129.41$, $130.55,131.54,135.75,135.87,138.81,140.26,140.31,141.75$, $141.78,142.17,142.23,142.50,142.77,142.78,143.25,144.82$, $144.89,145.51,145.53,145.61,145.64,145.67,145.92,146.41$, $146.42,146.66,146.68,147.79,147.82,156.69,163.37$ (3 signals are not described due to overlapping); UV-vis (toluene) $\lambda_{\max }(\mathrm{nm}): 435,706$; ESI-HRMS $(\mathrm{m} / \mathrm{z})$ calculated for $[\mathrm{M}+$ $\mathrm{Na}]^{+}=1034.0821$; found 1034.0856 .

Compound 3 c. $(21.6 \mathrm{mg}, 35 \%$ yield, dark brown solid). MW $\left(\mathrm{C}_{74} \mathrm{H}_{14} \mathrm{BrNO}_{2} \mathrm{~S}\right): 1060.89 \mathrm{~g} / \mathrm{mol}$; Rf: 0.85 (toluene); IR (ATR) $v$ $\left(\mathrm{cm}^{-1}\right): 2946,1352,1161,1087 ;{ }^{1} \mathrm{H}$ NMR $\left(400 \mathrm{MHz}, \mathrm{CDCl}_{3}\right) \delta$ (ppm): 2.89 (t, $J=4.8 \mathrm{~Hz}, 2 \mathrm{H}), 4.00(\mathrm{t}, J=4.8 \mathrm{~Hz}, 2 \mathrm{H}), 4.02-$ $4.12(\mathrm{~m}, 4 \mathrm{H}), 5.61(\mathrm{~d}, J=9.6 \mathrm{~Hz}, 1 \mathrm{H}), 6.93(\mathrm{~d}, J=9.6 \mathrm{~Hz}, 1 \mathrm{H})$, 7.68-7.78 (m, 4H); ${ }^{13} \mathrm{C}$ NMR $\left(101 \mathrm{MHz}, \mathrm{CDCl}_{3}\right) \delta(\mathrm{ppm})$ : $38.31,46.63,47.88,48.43,66.36$ (x2), 112.12, 127.30, 128.67, $128.74,131.49,132.96,135.70,135.84,138.11,139.27,140.31$, $140.35,141.78,141.80,142.20,142.24,142.50,142.52,142.80$, $142.81,143.34,144.86,144.91,145.48,145.62,145.65,145.68$, $145.93,146.45,146.69,146.71,147.83,147.84,156.54,156.60$ 
(4 signals are not described due to overlapping); UV-vis (toluene) $\lambda_{\max }(\mathrm{nm}): 436,705$; ESI-HRMS $(\mathrm{m} / \mathrm{z})$ calculated for $[\mathrm{M}+\mathrm{Na}]^{+}=1083.9806$; found 1083.9783 .

Compound 3 d. (24.7 mg, 37\% yield, dark brown solid). MW $\left(\mathrm{C}_{74} \mathrm{H}_{14} \mathrm{FNO}_{2} \mathrm{~S}\right.$ ): $999.99 \mathrm{~g} / \mathrm{mol}$; Rf: 0.75 (toluene); IR (ATR) $v$ $\left(\mathrm{cm}^{-1}\right): 2916,1340,1151,1089 ;{ }^{1} \mathrm{H}$ NMR $\left(400 \mathrm{MHz}, \mathrm{CDCl}_{3}\right) \delta$ (ppm): 2.90 (t, $J=4.8 \mathrm{~Hz}, 2 \mathrm{H}), 3.99$ (t, $J=4.8 \mathrm{~Hz}, 2 \mathrm{H}), 4.01-$ $4.15(\mathrm{~m}, 4 \mathrm{H}), 5.61(\mathrm{~d}, J=9.6 \mathrm{~Hz}, 1 \mathrm{H}), 6.93(\mathrm{~d}, J=9.6 \mathrm{~Hz}, 1 \mathrm{H})$, $7.24\left(\mathrm{t},{ }^{3} J_{\mathrm{H}-\mathrm{F}}=8.8,{ }^{3} J_{\mathrm{H}-\mathrm{H}}=8.8 \mathrm{~Hz}, 2 \mathrm{H}\right), 7.92(\mathrm{dd}, J=8.8 \mathrm{~Hz}$, $J=4.8 \mathrm{~Hz}, 2 \mathrm{H}) ;{ }^{13} \mathrm{C}$ NMR $\left(101 \mathrm{MHz}, \mathrm{CDCl}_{3}\right) \delta(\mathrm{ppm}): 38.37$, $46.54,47.90,48.44,66.32,66.33,111.90,117.00\left(\mathrm{~d},{ }^{2} J_{\mathrm{C}-\mathrm{F}}=\right.$ $22.4 \mathrm{~Hz}), 127.37,130.00\left(\mathrm{~d},{ }^{3} J_{\mathrm{C}-\mathrm{F}}=9.4 \mathrm{~Hz}\right), 131.47,135.14(\mathrm{~d}$, $\left.{ }^{4} J_{\mathrm{C}-\mathrm{F}}=3.4 \mathrm{~Hz}\right), 135.72,135.85,139.14,140.31,140.34,141.78$, $141.80,142.19,142.24,142.49,142.80,143.33,144.86,144.90$ $145.49,145.59,145.64,145.67,145.88,146.44,146.69,146.70$, $147.82,147.84,156.56,156.58,156.61,165.50\left(\mathrm{~d},{ }^{1} J_{\mathrm{C}-\mathrm{F}}=\right.$ $254.7 \mathrm{~Hz}$ ) (4 signals are not described due to overlapping); UVvis (toluene) $\lambda_{\max }(\mathrm{nm}): 435,704$; ESI-HRMS $(\mathrm{m} / \mathrm{z})$ calculated for $[\mathrm{M}+\mathrm{Na}]^{+}=1022.0621$; found 1022.0595 .

Compound 3 e. (19.8 mg, 35\% yield, dark brown solid). MW $\left(\mathrm{C}_{75} \mathrm{H}_{14} \mathrm{~F}_{3} \mathrm{NO}_{2} \mathrm{~S}\right): 1050.00 \mathrm{~g} / \mathrm{mol}$; Rf: 0.83 (toluene); IR (ATR) $v$ $\left(\mathrm{cm}^{-1}\right): 2914,1316,1163 ;{ }^{1} \mathrm{H}$ NMR $\left(400 \mathrm{MHz}, \mathrm{CDCl}_{3}\right) \delta$ (ppm): $2.94(\mathrm{t}, J=4.0 \mathrm{~Hz}, 2 \mathrm{H}), 4.02(\mathrm{t}, J=4.0 \mathrm{~Hz}, 2 \mathrm{H}), 4.00$ $4.15(\mathrm{~m}, 4 \mathrm{H}), 5.63(\mathrm{~d}, J=9.6 \mathrm{~Hz}, 1 \mathrm{H}), 6.94(\mathrm{~d}, J=9.6 \mathrm{~Hz}, 1 \mathrm{H})$, $7.86(\mathrm{~d}, J=8.2 \mathrm{~Hz}, 2 \mathrm{H}), 8.05(\mathrm{~d}, J=8.2 \mathrm{~Hz}, 2 \mathrm{H}) ;{ }^{13} \mathrm{C} \mathrm{NMR}$ $\left(101 \mathrm{MHz}, \mathrm{CDCl}_{3}\right) \delta(\mathrm{ppm}): 38.51,46.74,47.85,48.48,66.26$, $66.32,112.09,123.23\left(\mathrm{q},{ }^{1} J_{\mathrm{C}-\mathrm{F}}=271.4 \mathrm{~Hz}\right), 126.82\left(\mathrm{q},{ }^{4} J_{\mathrm{C}-\mathrm{F}}=\right.$ $3.6 \mathrm{~Hz}), 127.00,127.79,128.67,131.49,135.05\left(\mathrm{q},{ }^{2} J_{\mathrm{C}-\mathrm{F}}=\right.$ $32.9 \mathrm{~Hz}), 135.70,135.83,139.39,140.31,140.34,140.95$, $141.77,141.79,142.18,142.23,142.46,142.48,142.61,142.80$, $143.32,144.84,144.89,145.46,145.61,145.64,145.67,145.87$, $146.44,146.69,146.71,147.82,147.84,156.56$ (3 signals are not described due to overlapping; UV-vis (toluene) $\lambda_{\max }(\mathrm{nm})$ : 435, 704; ESI-HRMS $(\mathrm{m} / \mathrm{z})$ calculated for $[\mathrm{M}+\mathrm{Na}]^{+}=$ 1072.0590; found 1072.0568.

Compound 3 f. (16.6 mg, 25\% yield, dark brown solid). MW $\left(\mathrm{C}_{75} \mathrm{H}_{14} \mathrm{~F}_{3} \mathrm{NO}_{2} \mathrm{~S}\right): 1050.00 \mathrm{~g} / \mathrm{mol}$; Rf: 0.75 (toluene); IR (ATR) $v$ $\left(\mathrm{cm}^{-1}\right)$ : 2916, 1303, 1164; ${ }^{1} \mathrm{H}$ NMR $\left(400 \mathrm{MHz}, \mathrm{CDCl}_{3}\right) \delta$ (ppm): 2.98 (t, $J=4.6 \mathrm{~Hz}, 2 \mathrm{H}), 4.02$ (t, $J=4.6 \mathrm{~Hz}, 2 \mathrm{H}), 4.04-$ $4.15(\mathrm{~m}, 4 \mathrm{H}), 5.63(\mathrm{~d}, J=9.6 \mathrm{~Hz}, 1 \mathrm{H}), 6.95(\mathrm{~d}, J=9.6 \mathrm{~Hz}, 1 \mathrm{H})$, $7.73(\mathrm{t}, J=7.6 \mathrm{~Hz}, 1 \mathrm{H}), 7.77-7.82(\mathrm{~m}, 1 \mathrm{H}), 7.95(\mathrm{~d}, J=7.6 \mathrm{~Hz}$, 1H), $8.19(\mathrm{~d}, J=8.0 \mathrm{~Hz}, 1 \mathrm{H}) ;{ }^{13} \mathrm{C} \mathrm{NMR}\left(101 \mathrm{MHz}, \mathrm{CDCl}_{3}\right) \delta$ (ppm): $38.74,46.75,47.97,48.45,66.34(\times 2), 111.36,122.52$ $\left(\mathrm{q}, \quad{ }^{1} J_{\mathrm{C}-\mathrm{F}}=272.6 \mathrm{~Hz}\right), \quad 127.51, \quad 127.85, \quad 128.41 \quad\left(\mathrm{q}, \quad{ }^{2} J_{\mathrm{C}-\mathrm{F}}=\right.$ $33.4 \mathrm{~Hz}), 128.88\left(\mathrm{q},{ }^{3} J_{\mathrm{C}-\mathrm{F}}=6.4 \mathrm{~Hz}\right), 130.68,131.45,131.50$, $132.71,133.40,135.78,135.88,138.16(\mathrm{~m}), 139.13,140.31$, $140.36,141.77,141.81,142.19,142.25,142.50,142.52,142.79$, $142.80,143.33,144.85,144.92,145.52,145.59,145.64,145.66$, $145.88,146.44,146.67,146.70,147.81,147.85,156.65$ (2 signals are not described due to overlapping); UV-vis (toluene) $\lambda_{\max }(\mathrm{nm}): 435,705$; ESI-HRMS $(\mathrm{m} / \mathrm{z})$ calculated for $[\mathrm{M}+$ $\mathrm{Na}^{+}=1072.0590$; found 1072.0577 .

Compound 3 g. (28.3 mg, 49\% yield, dark brown solid). MW $\left(\mathrm{C}_{76} \mathrm{H}_{17} \mathrm{NO}_{4} \mathrm{~S}\right.$ ): $1040.04 \mathrm{~g} / \mathrm{mol}$; Rf: 0.38 (toluene); IR (ATR) $v$ $\left(\mathrm{cm}^{-1}\right): 2946,2360,1724,1273,1163 ;{ }^{1} \mathrm{H}$ NMR $(400 \mathrm{MHz}$, $\left.\mathrm{CDCl}_{3}\right) \delta(\mathrm{ppm}): 2.84(\mathrm{t}, J=4.8 \mathrm{~Hz}, 2 \mathrm{H}), 3.89(\mathrm{~s}, 3 \mathrm{H}), 3.99$ $4.10(\mathrm{~m}, 6 \mathrm{H}), 5.64(\mathrm{~d}, J=9.6 \mathrm{~Hz}, 1 \mathrm{H}), 6.95(\mathrm{~d}, J=9.5 \mathrm{~Hz}, 1 \mathrm{H})$, $7.96(\mathrm{~d}, J=8.2 \mathrm{~Hz}, 2 \mathrm{H}), 8.21(\mathrm{~d}, J=8.2 \mathrm{~Hz}, 2 \mathrm{H}) ;{ }^{13} \mathrm{C} \mathrm{NMR}$ $\left(101 \mathrm{MHz}, \mathrm{CDCl}_{3}\right) \delta$ (ppm): 38.26, 46.65, 48.00, 48.42, 52.93,
$66.41,66.47,112.82,127.31,127.37,130.92,131.47,134.62$ $135.76,135.89,139.50,140.38,140.43,141.84,141.88,142.27$, $142.33,142.54,142.87,142.89,142.97,143.31,144.91,144.99$, $145.55,145.61,145.72,145.74,146.02,146.53,146.77,147.89$, $147.92,156.59,156.64,165.55$ (5 signals are not described due to overlapping); UV-vis (toluene) $\lambda_{\max }(\mathrm{nm})$ : 436, 707; ESIHRMS $(\mathrm{m} / \mathrm{z})$ calculated for $[\mathrm{M}+\mathrm{Na}]^{+}=1062.0770$; found 1062.0758 .

Compound 3 h. (20.3 mg, 36\% yield, dark brown solid). MW $\left(\mathrm{C}_{74} \mathrm{H}_{14} \mathrm{~N}_{2} \mathrm{O}_{4} \mathrm{~S}\right.$ ): $1027.00 \mathrm{~g} / \mathrm{mol}$; Rf: 0.68 (toluene); IR (ATR) $v$ $\left(\mathrm{cm}^{-1}\right): 2958,1526,1346,1165,1087 ;{ }^{1} \mathrm{H}$ NMR $(400 \mathrm{MHz}$, $\left.\mathrm{CDCl}_{3}\right) \delta$ (ppm): $2.92(\mathrm{t}, J=4.4 \mathrm{~Hz}, 2 \mathrm{H}), 3.96-4.05(\mathrm{~m}, 4 \mathrm{H})$, $4.06(\mathrm{t}, J=4.4 \mathrm{~Hz}, 2 \mathrm{H}), 5.68(\mathrm{~d}, J=9.6 \mathrm{~Hz}, 1 \mathrm{H}), 6.93(\mathrm{~d}, J=$ $9.6 \mathrm{HZ}, 1 \mathrm{H}), 8.09(\mathrm{~d}, J=8.8 \mathrm{~Hz}, 2 \mathrm{H}), 8.41(\mathrm{~d}, J=8.8 \mathrm{~Hz}, 2 \mathrm{H})$; ${ }^{13} \mathrm{C}$ NMR $\left(101 \mathrm{MHz}, \mathrm{CDCl}_{3}\right) \delta(\mathrm{ppm}): 38.32,46.75,47.87$, $48.36,66.26,66.28,113.33,124.94,126.73,128.45,131.41$, $135.61,135.74,139.77,140.34,140.37,141.77,141.79,142.17$, $142.22,142.33,142.41,142.81,142.83,143.33,144.76,144.83$, $144.88,145.39,145.55,145.62,145.66,145.69,145.80,146.46$, $146.73,146.74,147.83,147.84,150.48,156.38,156.44$; UV-vis (toluene) $\lambda_{\max }(\mathrm{nm}): 435,705$; ESI-HRMS $(\mathrm{m} / \mathrm{z})$ calculated for $[\mathrm{M}+\mathrm{Na}]^{+}=1049.0566$; found 1049.0526.

Compound 3i. ( $27.8 \mathrm{mg}, 43 \%$ yield, dark brown solid). MW $\left(\mathrm{C}_{74} \mathrm{H}_{16} \mathrm{~N}_{2} \mathrm{O}_{2} \mathrm{~S}_{2}\right)$ : $997.01 \mathrm{~g} / \mathrm{mol}$; Rf: 0.40 (toluene); IR (ATR) $v$ $\left(\mathrm{cm}^{-1}\right): 2915,1343,1168,1103 ;{ }^{1} \mathrm{H}$ NMR $\left(400 \mathrm{MHz}, \mathrm{CDCl}_{3}\right) \delta$ (ppm): 2.42 (s, 3H), 3.10 (t, $J=4.6 \mathrm{~Hz}, 2 \mathrm{H}), 3.99-4.09$ (m, 4H), $4.13(\mathrm{t}, J=4.6 \mathrm{~Hz}, 2 \mathrm{H}), 5.55(\mathrm{~d}, J=9.6 \mathrm{~Hz}, 1 \mathrm{H}), 6.92(\mathrm{~d}, J=$ $9.6 \mathrm{~Hz}, 1 \mathrm{H}), 7.73(\mathrm{dd}, J=7.6 \mathrm{~Hz}, J=1.6 \mathrm{~Hz}, 1 \mathrm{H}), 7.95(\mathrm{~d}, J=$ $7.6 \mathrm{~Hz}, 1 \mathrm{H}), 8.58(\mathrm{~d}, J=1.6 \mathrm{~Hz}, 1 \mathrm{H}) ;{ }^{13} \mathrm{C}$ NMR $(101 \mathrm{MHz}$, $\left.\mathrm{CDCl}_{3}\right) \delta$ (ppm): 18.82, 39.12, 47.27, 47.95, 48.42, 66.36, $66.37,111.29,122.43,128.12,131.34,135.82,135.92,137.93$, $138.41,139.14,140.31,140.33,141.78,141.79,142.19,142.24$, $142.50,142.51,142.79,143.31,144.87,144.92,145.58,145.60$, $145.63,145.65,145.70,145.87,146.43,146.66,146.69,147.81$, $147.84,151.11,154.16,156.75$ (4 signals are not described due to overlapping); UV-vis (toluene) $\lambda_{\max }(\mathrm{nm})$ : 435, 704; ESIHRMS $(\mathrm{m} / \mathrm{z})$ calculated for $[\mathrm{M}+\mathrm{Na}]^{+}=1019.0825$; found 1019.0808 .

Compound 3 j. (37.2 mg, 53\% yield, dark brown solid). MW $\left(\mathrm{C}_{72} \mathrm{H}_{13} \mathrm{NO}_{2} \mathrm{~S}_{2}\right): 988.02 \mathrm{~g} / \mathrm{mol}$; Rf: 0.75 (toluene); IR (ATR) $v$ $\left(\mathrm{cm}^{-1}\right)$ : 2917, 1349, 1158; ${ }^{1} \mathrm{H}$ NMR $\left(400 \mathrm{MHz}, \mathrm{CDCl}_{3}\right) \delta$ (ppm): 2.96 (t, $J=4.6 \mathrm{~Hz}, 2 \mathrm{H}), 4.03(\mathrm{t}, J=4.6 \mathrm{~Hz}, 2 \mathrm{H}), 4.03-$ $4.18(\mathrm{~m}, 4 \mathrm{H}), 5.64(\mathrm{~d}, J=9.6 \mathrm{~Hz}, 1 \mathrm{H}), 6.91(\mathrm{~d}, J=9.6 \mathrm{~Hz}, 1 \mathrm{H})$, 7.14 (dd, $J=4.8 \mathrm{~Hz}, J=4.0 \mathrm{~Hz}, 1 \mathrm{H}), 7.64$ (dd, $J=4.8 \mathrm{~Hz}, J=$ $1.2 \mathrm{~Hz}, 1 \mathrm{H}), 7.67(\mathrm{dd}, J=4.0 \mathrm{~Hz}, J=1.2 \mathrm{~Hz}, 1 \mathrm{H}) ;{ }^{13} \mathrm{C} \mathrm{NMR}$ $\left(101 \mathrm{MHz}, \mathrm{CDCl}_{3}\right) \delta(\mathrm{ppm}): 38.25,46.50,47.93,48.39,66.18$ $(\times 2), 112.14,127.14,127.74,131.38,132.33,132.78,135.73$, $135.81,139.07,139.56,140.23,140.27,141.67,141.70,142.07$, $142.13,142.37,142.38,142.69,143.22,144.73,144.79,145.36$, $145.51,145.53,145.57,145.73,146.32,146.55,146.58,147.67$, $147.70,156.38,156.43$ (4 signals are not described due to overlapping); UV-vis (toluene) $\lambda_{\max }(\mathrm{nm}): 436,705$; ESI-HRMS $(\mathrm{m} / \mathrm{z})$ calculated for $[\mathrm{M}+\mathrm{Na}]^{+}=1010.0280$; found 1010.0268 .

Compound 3 k. (23.3 mg, 33\% yield, dark brown solid). MW $\left(\mathrm{C}_{73} \mathrm{H}_{23} \mathrm{NO}_{2} \mathrm{SSi}\right): 1006.14 \mathrm{~g} / \mathrm{mol}$; Rf: 0.65 (toluene); IR (ATR) $v$ $\left(\mathrm{cm}^{-1}\right): 2915,1340,1144 ;{ }^{1} \mathrm{H}$ NMR $\left(400 \mathrm{MHz}, \mathrm{CDCl}_{3}\right) \delta$ (ppm): 0.09 (s, 9H), 1.08-1.14 (m, 2H), 3.07-3.13 (m, 2H), $3.19(\mathrm{t}, J=4.6 \mathrm{~Hz}, 2 \mathrm{H}), 4.07(\mathrm{t}, J=4.6 \mathrm{~Hz}, 2 \mathrm{H}), 4.07-4.19(\mathrm{~m}$, $4 \mathrm{H}), 5.52(\mathrm{~d}, J=9.6 \mathrm{~Hz}, 1 \mathrm{H}), 6.80(\mathrm{~d}, J=9.6 \mathrm{~Hz}, 1 \mathrm{H}) ;{ }^{13} \mathrm{C}$ 
NMR $\left(101 \mathrm{MHz}, \mathrm{CDCl}_{3}\right) \delta(\mathrm{ppm}):-1.72,10.53,39.75,46.62$, $47.97,48.54,49.41,66.32,66.40,109.71,128.38,131.75$, $135.80,135.88,138.30,140.35,141.80,141.81,142.21,142.25$, $142.56,142.80,143.32,144.88,144.92,145.59,145.62,145.64$, $145.67,145.69,145.93,146.44,146.68,146.71,147.82,147.84$ 156.76 (6 signals are not described due to overlapping); UV-vis (toluene) $\lambda_{\max }(\mathrm{nm}): 435,707$; ESI-HRMS $(\mathrm{m} / \mathrm{z})$ calculated for $[\mathrm{M}+\mathrm{Na}]^{+}=1028.1111$; found 1028.1121 .

Compound 31. (20.8 mg, 36\% yield, dark brown solid). MW $\left(\mathrm{C}_{72} \mathrm{H}_{19} \mathrm{NO}_{2} \mathrm{~S}\right.$ ): $962.01 \mathrm{~g} / \mathrm{mol}$; Rf: 0.38 (toluene); IR (ATR) $v$ $\left(\mathrm{cm}^{-1}\right)$ : 2920, 1314, 1128; ${ }^{1} \mathrm{H}$ NMR $\left(400 \mathrm{MHz}, \mathrm{CDCl}_{3}\right) \delta$ (ppm): 1.52 (s, 9H), $3.20(\mathrm{t}, J=4.4 \mathrm{~Hz}, 2 \mathrm{H}), 4.00-4.17(\mathrm{~m}, 4 \mathrm{H})$, $4.16(\mathrm{t}, J=4.4 \mathrm{~Hz}, 2 \mathrm{H}), 5.46(\mathrm{~d}, J=9.6 \mathrm{~Hz}, 1 \mathrm{H}), 6.81(\mathrm{~d}, J=$ $9.6 \mathrm{~Hz}, 1 \mathrm{H}) ;{ }^{13} \mathrm{C}$ NMR $\left(101 \mathrm{MHz}, \mathrm{CDCl}_{3}\right) \delta(\mathrm{ppm}): 25.07$, 39.90, 47.89, 48.27, 48.54, 62.97, 66.38, 66.45, 109.06, 130.29, $131.72,135.87,135.92,138.32,140.35,141.80,141.81,142.21$, $142.25,142.53,142.54,142.80,143.34,144.88,144.92,145.62$ $145.65,145.67,145.72,145.96,146.44,146.69,146.72,147.82$ $147.84,156.79$ (6 signals are not described due to overlapping); UV-vis (toluene) $\lambda_{\max }(\mathrm{nm}): 435,706 ;$ ESI-HRMS $(\mathrm{m} / \mathrm{z})$ calculated for $[\mathrm{M}+\mathrm{Na}]^{+}=984.1029$; found 984.1014.

Compound $3 \mathrm{~m}$. (19.7 mg, 27\% yield, dark brown solid). MW $\left(\mathrm{C}_{75} \mathrm{H}_{20} \mathrm{O}_{4}\right): 984.98 \mathrm{~g} / \mathrm{mol}$; Rf: 0.53 (toluene); IR (ATR) $v$ $\left(\mathrm{cm}^{-1}\right): 2916,1723,1423,1225,1040 ;{ }^{1} \mathrm{H}$ NMR $(400 \mathrm{MHz}$ $\left.\mathrm{CDCl}_{3}\right) \delta(\mathrm{ppm}): 1.32(\mathrm{t}, J=7.2 \mathrm{~Hz}, 6 \mathrm{H}), 2.68$ (t, $J=6.0 \mathrm{~Hz}$, $2 \mathrm{H}), 3.03(\mathrm{t}, J=6.0 \mathrm{~Hz}, 2 \mathrm{H}), 4.05-4.14(\mathrm{~m}, 4 \mathrm{H}), 4.26-4.34(\mathrm{~m}$, $4 \mathrm{H}), 6.15(\mathrm{~d}, J=12.2 \mathrm{~Hz}, 1 \mathrm{H}), 6.40(\mathrm{~d}, J=12.2 \mathrm{~Hz}, 1 \mathrm{H}) ;{ }^{13} \mathrm{C}$ NMR (101 MHz, $\left.\mathrm{CDCl}_{3}\right) \delta(\mathrm{ppm}): 14.39,31.40,33.73,47.90$, $48.76,61.23,62.22,66.27,66.47,128.73,131.32,131.49$, $136.12,136.13,136.15,136.16,140.40,141.90,142.32,142.35$, $142.62,142.67,142.87,143.41,143.77,144.98,145.01,145.72$, $145.75,145.84,146.09,146.52,146.76,146.79,147.91,147.94$, $156.84,156.88,170.84$ (5 signals are not described due to overlapping); UV-vis (toluene) $\lambda_{\max }(\mathrm{nm}): 436,707$; ESI-HRMS $(\mathrm{m} / \mathrm{z})$ calculated for $[\mathrm{M}+\mathrm{Na}]^{+}=1007.1254$; found 1007.1260

Compound 3 n. (17.7 mg, 32\% yield, dark brown solid). MW $\left(\mathrm{C}_{77} \mathrm{H}_{18} \mathrm{O}_{2}\right): 974.99 \mathrm{~g} / \mathrm{mol}$; Rf: 0.79 (toluene); IR (ATR) $v$ $\left(\mathrm{cm}^{-1}\right): 2916,1725,1425,1214 ;{ }^{1} \mathrm{H}$ NMR $\left(400 \mathrm{MHz}, \mathrm{CDCl}_{3}\right) \delta$ (ppm): 2.45-2.61 (m, 1H), 2.66-2.76 (m, 2H), 2.77-2.89 (m, $1 \mathrm{H}), 3.80(\mathrm{~s}, 3 \mathrm{H}), 3.81-3.93(\mathrm{~m}, 1 \mathrm{H}), 3.96-4.08(\mathrm{~m}, 1 \mathrm{H}), 4.08$ $4.33(\mathrm{~m}, 2 \mathrm{H}), 6.40(\mathrm{~d}, J=12.2 \mathrm{~Hz}, 1 \mathrm{H}), 6.52(\mathrm{~d}, J=12.2 \mathrm{~Hz}$, $1 \mathrm{H}), 7.26\left(1 \mathrm{H}\right.$, overlapped with $\mathrm{CDCl}_{3}$ signal, observable in the COSY-NMR spectra) 7.36-7.44 (m, 4H); ${ }^{13} \mathrm{C}$ NMR (101 MHz, $\left.\mathrm{CDCl}_{3}\right) \delta(\mathrm{ppm}): 33.67,34.61,48.32,48.46,52.92,58.69$, $66.13,66.66,100.14,127.02,127.39,129.08,131.22,131.28$, $132.97,140.18,140.22,140.29,140.32,140.36,141.75,141.80$, $141.84,142.17,142.20,142.26,142.28,142.49,142.53,142.55$, $142.76,142.79,143.30,143.37,143.73143 .76,144.88,144.90$, $144.93,145.53,145.62,145.64,145.67,145.70,145.74,145.84$, $145.93,146.00,146.39,146.42,146.43,146.65,146.68,147.78$, $147.82,147.84,156.64,156.67,175.43$ (18 signals are not described due to overlapping); UV-vis (toluene) $\lambda_{\max }(\mathrm{nm}): 436$, 706; ESI-HRMS $(\mathrm{m} / \mathrm{z})$ calculated for $[\mathrm{M}+\mathrm{Na}]^{+}=997.1199$; found 997.1178

Compound 3 o. (22.0 mg, 39\% yield, dark brown solid). MW $\left(\mathrm{C}_{76} \mathrm{H}_{18} \mathrm{O}_{2} \mathrm{~S}\right)$ : $995.04 \mathrm{~g} / \mathrm{mol}$; Rf: $0.55\left(\mathrm{CH}_{2} \mathrm{Cl}_{2}\right)$; IR (ATR) $v$ $\left(\mathrm{cm}^{-1}\right): 2914,1300,1130 ;{ }^{1} \mathrm{H}$ NMR $\left(400 \mathrm{MHz}, \mathrm{CDCl}_{3}\right) \delta$ (ppm): $2.70-2.82(\mathrm{~m}, 2 \mathrm{H}), 2.83(\mathrm{~s}, 3 \mathrm{H}), 2.92-3.06(\mathrm{~m}, 1 \mathrm{H})$, 3.24-3.34 (m, 1H) 3.64-3.86 (m, 1H), 3.89-4.05 (m, 1H), $4.06-4.41(\mathrm{~m}, 2 \mathrm{H}), 6.53(\mathrm{~d}, J=12.0 \mathrm{~Hz}, 1 \mathrm{H}), 6.69(\mathrm{~d}, J=$ $12.0 \mathrm{~Hz}, 1 \mathrm{H}), 7.35(\mathrm{t}, J=7.5 \mathrm{~Hz}, 1 \mathrm{H}), 7.44(\mathrm{t}, J=7.5 \mathrm{~Hz}, 2 \mathrm{H})$, $7.72(\mathrm{~d}, J=7.5 \mathrm{~Hz}, 2 \mathrm{H}) ;{ }^{13} \mathrm{C}$ NMR $\left(101 \mathrm{MHz}, \mathrm{CDCl}_{3}\right) \delta(\mathrm{ppm})$ : 29.03, 33.63, 36.35, 47.89, 48.24, 65.88, 66.39, 74.67, 128.15, $129.33,129.48,129.54,131.01,133.23,134.96,135.00,135.70$, $135.76,135.96,140.15,140.22,140.30,140.37,141.71,141.75$, $141.79,141.85,142.14,142.17,142.24,142.27,142.39,142.46$, $142.51,142.77,142.79,143.30,143.33,144.20,144.21,144.85$, $144.86,144.87,145.23,145.24,145.33,145.52,145.55,145.60$, $145.62,145.63,145.65,145.67,145.73,145.78,145.95,146.37$, $146.41,146.44,146.58,146.65,146.69,147.81,155.89,156.23$, $156.25,156.45$ (9 signals are not described due to overlapping); UV-vis (toluene) $\lambda_{\max }(\mathrm{nm}): 426,700 ;$ ESI-HRMS $(\mathrm{m} / \mathrm{z})$ calculated for $[\mathrm{M}+\mathrm{Na}]^{+}=1017.0920$; found 1017.0899.

Compound 3 p. (13.1 mg, 22\% yield, dark brown solid). MW $\left(\mathrm{C}_{81} \mathrm{H}_{20} \mathrm{O}_{2} \mathrm{~S}\right)$ : $1057.11 \mathrm{~g} / \mathrm{mol}$; Rf: 0.51 (toluene); IR (ATR) $v$ $\left(\mathrm{cm}^{-1}\right): 2914,1294,1139 ;{ }^{1} \mathrm{H}$ NMR $\left(400 \mathrm{MHz}, \mathrm{CDCl}_{3}\right) \delta$ (ppm): $2.66-3.03(\mathrm{~m}, 3 \mathrm{H}), 3.20-3.34(\mathrm{~m}, 1 \mathrm{H}), 3.85(\mathrm{~d}, J=$ $10.6 \mathrm{~Hz}, 1 \mathrm{H}), 4.08(\mathrm{~d}, J=11.0 \mathrm{~Hz}, 1 \mathrm{H}), 4.43(\mathrm{~d}, J=10.6 \mathrm{~Hz}$, $1 \mathrm{H}), 4.47(\mathrm{~d}, J=11.0 \mathrm{~Hz}, 1 \mathrm{H}), 4.99(\mathrm{~d}, J=7.6 \mathrm{~Hz}, 1 \mathrm{H}), 5.83(\mathrm{~d}$, $J=7.6 \mathrm{~Hz}, 1 \mathrm{H}), 7.28-7.39(\mathrm{~m}, 5 \mathrm{H}), 7.62-7.72(\mathrm{~m}, 2 \mathrm{H}), 7.73-$ $7.81(\mathrm{~m}, 1 \mathrm{H}), 8.07-8.15(\mathrm{~m}, 2 \mathrm{H}) ;{ }^{13} \mathrm{C}$ NMR $\left(101 \mathrm{MHz}, \mathrm{CDCl}_{3}\right)$ $\delta$ (ppm): 29.80, 33.60, 48.96, 49.57, 65.54, 66.61, 74.08, $118.35,125.45,126.20,126.68,127.99,128.38,128.66,129.19$, $129.32,129.69,134.25,135.67,135.88,136.01,136.06,138.33$, $138.63,138.66,140.28,140.31,140.33,140.40,141.78,141.79$, $141.82,141.84,142.12,142.16,142.18,142.21,142.26,142.29$, $142.36,142.39,142.48,142.49,142.56,142.61,142.77,142.81$, $142.84,142.86,143.23,143.93,144.82,144.85,144.87,144.93$, $145.32,145.51,145.54,145.57,145.59,145.72,145.73,145.88$, $145.89,145.92,146.02,146.05,146.45,146.67,146.69,146.71$, $146.74,147.80,147.85,148.08,149.98,155.95,156.03,156.75$, 157.10 ( 1 signal is not described due to overlapping); UV-vis (toluene) $\lambda_{\max }(\mathrm{nm}): 435,700$; ESI-HRMS $(\mathrm{m} / \mathrm{z})$ calculated for $[\mathrm{M}+\mathrm{Na}]^{+}=1079.1076$; found 1079.1074.

\section{Experimental Procedure for the Synthesis of Fused Dihydroazepine Derivatives of $\mathrm{C}_{70}(4 \mathrm{a})$}

In a $10 \mathrm{~mL}$ capped vial under a nitrogen inert atmosphere, a solution of $\left[\mathrm{Rh}(\mathrm{cod}){ }_{2}\right] \mathrm{BF}_{4}(5.3 \mathrm{mg}, 0.01 \mathrm{mmol})$ and $(R)-$ DTBM-segphos $(13.5 \mathrm{mg}, 0.01 \mathrm{mmol})$ in anhydrous $\mathrm{CH}_{2} \mathrm{Cl}_{2}$ $(4 \mathrm{~mL})$ was prepared. Hydrogen gas was bubbled into the catalyst solution for $30 \mathrm{~min}$ before it was concentrated to dryness, dissolved in anhydrous $o$-DCB and introduced into a solution of $\mathrm{C}_{70}(100 \mathrm{mg}, 0.12 \mathrm{mmol})$ and bisallene $1 \mathrm{a}(31.1 \mathrm{mg}$, $0.11 \mathrm{mmol})$ in anhydrous $o$-DCB $(1.4 \mathrm{mM})$, preheated to $90^{\circ} \mathrm{C}$. The resulting mixture was stirred at $90^{\circ} \mathrm{C}$ for $40 \mathrm{~min}$ (TLC monitoring), allowed to cool down to room temperature and directly subjected to column chromatography on silica gel using $\mathrm{CS}_{2}$ as the eluent to provide unreacted $\mathrm{C}_{70}$. Further elution with toluene gave the mixture compounds $\boldsymbol{\alpha}-\mathbf{4}$ a and $\boldsymbol{\beta}-\mathbf{4}$ a $(57.4 \mathrm{mg}$, $46 \%$ in a $3: 1$ ratio) as a dark solid.

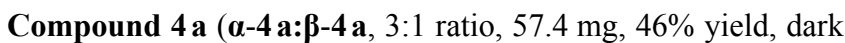
brown solid). MW $\left(\mathrm{C}_{85} \mathrm{H}_{17} \mathrm{NO}_{2} \mathrm{~S}\right): 1116.14 \mathrm{~g} / \mathrm{mol}$; Rf: 0.63 (toluene); IR (ATR) $v\left(\mathrm{~cm}^{-1}\right): 3046,1414,1158,1087 ;{ }^{1} \mathrm{H}$ NMR $\left(400 \mathrm{MHz}, \mathrm{CDCl}_{3}\right) \delta(\mathrm{ppm}): 2.29(\mathrm{~s}, 3 \mathrm{H}, \boldsymbol{\alpha}), 2.50(\mathrm{~s}, 3 \mathrm{H}, \boldsymbol{\beta})$, 2.52-2.57 (m, 2H, $\boldsymbol{\alpha}), 2.73-2.77(\mathrm{~m}, 2 \mathrm{H}, \boldsymbol{\beta}), 3.11-3.19(\mathrm{~m}, 2 \mathrm{H}$, $\boldsymbol{\alpha}+\boldsymbol{\beta}), 3.52(\mathrm{~m}, 2 \mathrm{H}, \boldsymbol{\beta}), 3.55(\mathrm{~m}, 2 \mathrm{H}, \boldsymbol{\alpha}), 3.79(\mathrm{t}, J=4.4 \mathrm{~Hz}, 2 \mathrm{H}$, a), $3.86(\mathrm{t}, J=4.4 \mathrm{~Hz}, 2 \mathrm{H}, \boldsymbol{\beta}), 5.23(\mathrm{~d}, J=9.2 \mathrm{~Hz}, 1 \mathrm{H}, \boldsymbol{\beta}), 5.51$ 
$(\mathrm{d}, J=9.6 \mathrm{~Hz}, 1 \mathrm{H}, \boldsymbol{\alpha}), 6.83(\mathrm{~d}, J=9.2 \mathrm{~Hz}, 1 \mathrm{H}, \boldsymbol{\beta}), 6.93(\mathrm{~d}, J=$ $9.6 \mathrm{~Hz}, 1 \mathrm{H}, \alpha), 7.29(\mathrm{~d}, J=8.0 \mathrm{~Hz}, 2 \mathrm{H}, \boldsymbol{\alpha}), 7.34(\mathrm{~d}, J=8.0 \mathrm{~Hz}$, $2 \mathrm{H}, \boldsymbol{\beta}), 7.73(\mathrm{~d}, J=8.0 \mathrm{~Hz}, 2 \mathrm{H}, \boldsymbol{\alpha}), 7.74(\mathrm{~d}, J=8.0 \mathrm{~Hz}, 2 \mathrm{H}, \boldsymbol{\beta})$; ${ }^{13} \mathrm{C}$ NMR $\left(101 \mathrm{MHz}, \mathrm{CDCl}_{3}\right) \delta(\mathrm{ppm}): 21.77,38.09,44.56$, $46.19,47.77,57.90,59.75,111.08,125.44,127.25,127.76$, $130.24,130.27,130.32,130.36,131.47,131.49,131.58,133.98$ $134.01,135.98,137.17,137.18,140.34,142.94,143.15,143.20$, $143.35,144.25,145.95,146.53,147.18,147.21,147.20,147.64$, $149.04,149.22,149.60,149.66,150.01,150.09,150.12,150.87$, $151.41,151.53,151.55,151.62,155.32,161.18$ (only the major product $\alpha-4 \mathrm{a}$ is identified); UV-vis (toluene) $\lambda \max (\mathrm{nm}) \boldsymbol{\alpha}-\mathbf{4} \mathbf{a}$ : 399, 461; UV-vis (toluene) $\lambda_{\max }$ (nm) $\boldsymbol{\beta}-4$ a: 365, 399; ESI$\operatorname{HRMS}(\mathrm{m} / \mathrm{z})$ calculated for $[\mathrm{M}+\mathrm{Na}]^{+}=1138.0872$; found 1138.0841

\section{General Procedure for the Reduction of Fused Dihydroazepine Derivatives (5 a)}

In a $25 \mathrm{~mL}$ round-bottom flask under a nitrogen inert atmosphere and equipped with magnetic stirrer, a solution of $\mathbf{3}$ a (100.0 $\mathrm{mg}, 0.10 \mathrm{mmol})$ in anhydrous $\mathrm{CH}_{2} \mathrm{Cl}_{2}(10 \mathrm{~mL})$ was stirred and cooled at $0{ }^{\circ} \mathrm{C}$. $\mathrm{Et}_{3} \mathrm{SiH}(0.15 \mathrm{~mL}, 0.9 \mathrm{mmol})$ and $\mathrm{BF}_{3} \cdot \mathrm{Et}_{2} \mathrm{O}(0.1 \mathrm{~mL}, 0.81 \mathrm{mmol})$ was then added and the resulting mixture was stirred for $5 \mathrm{~h}$ at room temperature (TLC monitoring) and directly subjected to column chromatography on silica using toluene as the eluent to provide compound $\mathbf{5}$ a $(82.1 \mathrm{mg}, 82 \%)$ as a dark brown solid.

Compound 5 a. ( $82.1 \mathrm{mg}, 82 \%$ yield, dark brown solid). MW $\left(\mathrm{C}_{75} \mathrm{H}_{19} \mathrm{NO}_{2} \mathrm{~S}\right.$ ): $998.04 \mathrm{~g} / \mathrm{mol}$; Rf: 0.20 (toluene); IR (ATR) $v$ $\left(\mathrm{cm}^{-1}\right): 2917,1424,1150,1090 ;{ }^{1} \mathrm{H}$ NMR $\left(400 \mathrm{MHz}, \mathrm{CDCl}_{3}\right) \delta$ (ppm): $2.38(\mathrm{~s}, 3 \mathrm{H}), 2.91(\mathrm{t}, J=4.8 \mathrm{~Hz}, 4 \mathrm{H}), 3.66-3.71(\mathrm{~m}$, $4 \mathrm{H}), 3.95(\mathrm{~s}, 4 \mathrm{H}), 7.31(\mathrm{~d}, J=8.0 \mathrm{~Hz}, 2 \mathrm{H}), 7.75(\mathrm{~d}, J=8.0 \mathrm{~Hz}$, $2 \mathrm{H}) ;{ }^{13} \mathrm{C}$ NMR $\left(101 \mathrm{MHz}, \mathrm{CDCl}_{3}\right) \delta(\mathrm{ppm}): 21.72,35.91,47.81$, $48.41,66.40,127.39,129.99,135.75,135.85,137.41,140.30$, $141.76,142.20,142.53,142.79,143.27,143.52,144.85,145.56$, $145.63,145.90,146.42,146.67,147.80,156.80$ (one signal is not described due to overlapping); UV-vis (toluene) $\lambda_{\max }(\mathrm{nm})$ : 434, 705; ESI-HRMS $(\mathrm{m} / \mathrm{z})$ calculated for $[\mathrm{M}+\mathrm{Na}]^{+}=$ 1020.1029; found 1020.1005 .

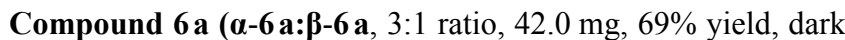
brown solid). MW $\left(\mathrm{C}_{85} \mathrm{H}_{19} \mathrm{NO}_{2} \mathrm{~S}\right) ; 1118.15 \mathrm{~g} / \mathrm{mol} ; \mathrm{Rf}: 0.25$ (toluene); IR (ATR) $v\left(\mathrm{~cm}^{-1}\right): 2904,1423,1154,10889 ;{ }^{1} \mathrm{H}$ NMR $\left(400 \mathrm{MHz}, \mathrm{CDCl}_{3}\right) \delta(\mathrm{ppm}): 2.35(\mathrm{~s}, 3 \mathrm{H}, \boldsymbol{\alpha}), 2.50(\mathrm{~s}, 3 \mathrm{H}$ $\boldsymbol{\beta}), 2.51(\mathrm{~m}, 2 \mathrm{H}, \boldsymbol{\beta}), 2.61(\mathrm{t}, J=5.2 \mathrm{~Hz}, 2 \mathrm{H}, \boldsymbol{\alpha}), 2.61(\mathrm{~m}, 2 \mathrm{H}, \boldsymbol{\beta})$, $2.81(\mathrm{t}, J=5.2 \mathrm{~Hz}, 2 \mathrm{H}, \boldsymbol{\alpha}), 2.93(\mathrm{~d}, J=14 \mathrm{~Hz}, 2 \mathrm{H}, \boldsymbol{\beta}), 3.07$ (s, $2 \mathrm{H}, \boldsymbol{\alpha}), 3.09$ (d, $J=14 \mathrm{~Hz}, 2 \mathrm{H}, \boldsymbol{\beta}), 3.40(\mathrm{~m}, 2 \mathrm{H}, \boldsymbol{\beta}), 3.45(\mathrm{~s}, 2 \mathrm{H}$, $\boldsymbol{\alpha}), 3.49(\mathrm{~m}, 2 \mathrm{H}, \boldsymbol{\beta}), 3.52(\mathrm{~m}, 2 \mathrm{H}, \boldsymbol{\alpha}), 3.62(\mathrm{~m}, 2 \mathrm{H}, \boldsymbol{\alpha}), 7.29(\mathrm{~d}$, $J=8.0 \mathrm{~Hz}, 2 \mathrm{H}, \boldsymbol{\alpha}), 7.38(\mathrm{~d}, J=8.0 \mathrm{~Hz}, 2 \mathrm{H}, \boldsymbol{\beta}), 7.71(\mathrm{~d}, J=$ $8.0 \mathrm{~Hz}, 2 \mathrm{H}+2 \mathrm{H}, \boldsymbol{\alpha}+\boldsymbol{\beta}) ;{ }^{13} \mathrm{C} \mathrm{NMR}\left(101 \mathrm{MHz}, \mathrm{CDCl}_{3}\right) \delta(\mathrm{ppm})$ : 21.75, 35.70, 35.86, 44.53, 47.46, 47.68, 48.30, 57.88, 59.77, $127.36,128.37,129.19,129.98,131.49,131.60,133.97,134.04$ $135.73,135.86,136.31,137.18,140.41,140.66,142.28,142.94$, $143.16,143.20,143.37,143.55,145.95,146.45,146.57,147.19$, $147.23,147.65,148.31,149.04,149.22,149.60,149.66,150.07$, $150.10,150.86,150.89,151.38,151.61,155.25,161.40$ (only the major product $\boldsymbol{\alpha}-\mathbf{6 a}$ is identified); UV-vis (toluene) $\lambda_{\max }$ $(\mathrm{nm})$ : 398, 449 (only the major product $\boldsymbol{\alpha - 6} \mathbf{a}$ is identified); ESI$\operatorname{HRMS}(\mathrm{m} / \mathrm{z})$ calculated for $[\mathrm{M}+\mathrm{Na}]^{+}=1140,1029$; found 1140.0985 .

\section{Acknowledgements}

We are grateful for the financial support by the Spanish Ministry of Economy and Competitivity (MINECO) (Projects CTQ2017-85341-P and CTQ2017-83587-P, FPI predoctoral grant to A.A. and C.C.) and the Generalitat de Catalunya (Project 2017-SGR-39).

\section{References}

[1] A. Montellano López, A. Mateo-Alonso, M. Prato, J. Mater. Chem. 2011, 21, 1305-1318.

[2] E. Castro, A. H. Garcia, G. Zavala, L. Echegoyen, J. Mater. Chem. B 2017, 5, 6523-6535.

[3] F. Cataldo, T. Da Ros, Medicinal Chemistry and Pharmacological Potential of Fullerenes and Carbon Nanotubes; F. Cataldo, T. Da Ros, Eds.; Carbon Materials: Chemistry and Physics; Springer Netherlands: Dordrecht, 2008; Vol. 1.

[4] N. Panwar, A. M. Soehartono, K. K. Chan, S. Zeng, G. $\mathrm{Xu}, \mathrm{J} . \mathrm{Qu}, \mathrm{P}$. Coquet, K. T. Yong, X. Chen, Chem. Rev. 2019, 119, 9559-9656.

[5] S. Collavini, J. L. Delgado, Sustain. Energy Fuels 2018 2, 2480-2493.

[6] E. Castro, J. Murillo, O. Fernandez-Delgado, L. Echegoyen, J. Mater. Chem. C 2018, 6, 2635-2651.

[7] T. Umeyama, H. Imahori, Acc. Chem. Res. 2019, 52, 2046-2055.

[8] L. Jia, M. Chen, S. Yang, Mater. Chem. Front. 2020, 4, 2256-2282.

[9] O. Fernandez-Delgado, P. S. Chandrasekhar, N. CanoSampaio, Z. C. Simon, A. R. Puente-Santiago, F. Liu, E. Castro, L. Echegoyen, J. Mater. Chem. C 2021, DOI: $10.1039 / \mathrm{d} 0 \mathrm{tc} 05903 \mathrm{j}$.

[10] W. Krätschmer, L. D. Lamb, K. Fostiropoulos, D. R. Huffman, Nature 1990, 347, 354-358.

[11] A. Hirsch, M. Brettreich, Fullerenes: Chemistry and Reactions; Wiley-VCH, Weinheim, 2005.

[12] C. Bingel, Chem. Ber. 1993, 126, 1957-1959.

[13] J. Ramos-Soriano, J. J. Reina, B. M. Illescas, N. de la Cruz, L. Rodríguez-Pérez, F. Lasala, J. Rojo, R. Delgado, N. Martín, J. Am. Chem. Soc. 2019, 141, 15403-15412.

[14] K. Yan, J. Chen, H. Ju, F. Ding, H. Chen, C. Z. Li, J. Mater. Chem. A 2018, 6, 15495-15503.

[15] M. Maggini, G. Scorrano, M. Prato, J. Am. Chem. Soc. 1993, 115, 9798-9799.

[16] B. Li, J. Zhen, Y. Wan, X. Lei, L. Jia, X. Wu, H. Zeng, M. Chen, G. W. Wang, S. Yang, J. Mater. Chem. A 2020, 8, 3872-3881.

[17] Z. S. Martinez, E. Castro, C.-S. Seong, M. R. Cerón, L. Echegoyen, M. Llano, Antimicrob. Agents Chemother. 2016, 60, 5731-5741.

[18] J. B. Briggs, G. P. Miller, C. R. Chim. 2006, 9, 916-927.

[19] W. Śliwa, Fullerene Sci. Technol. 1997, 5, 1133-1175.

[20] G.-W. Wang, M. Saunders, R. J. Cross, J. Am. Chem. Soc. 2001, 123, 256-259. 
[21] X. Meng, G. Zhao, Q. Xu, Z. Tan, Z. Zhang, L. Jiang, C. Shu, C. Wang, Y. Li, Adv. Funct. Mater. 2014, 24, 158163.

[22] Y. He, G. Zhao, B. Peng, Y. Li, Adv. Funct. Mater. 2010 20, 3383-3389.

[23] G.-W. Wang, F.-B. Li, Curr. Org. Chem. 2012, 16, 11091127.

[24] G. W. Wang, Top. Organomet. Chem. 2016, 55, 119-136.

[25] E. Castro, A. Artigas, A. Pla-Quintana, A. Roglans, F. Liu, F. Perez, A. Lledó, X.-Y. Zhu, L. Echegoyen, Materials 2019, 12, 1314-1322.

[26] A. Artigas, A. Pla-Quintana, A. Lledó, A. Roglans, M. Solà, Chem. Eur. J. 2018, 24, 10653-10661.

[27] A. Artigas, A. Lledó, A. Pla-Quintana, A. Roglans, M. Solà, Chem. Eur. J. 2017, 23, 15067-15072.

[28] T. Y. Hsiao, K. C. Santhosh, K. F. Liou, C. H. Cheng, J. Am. Chem. Soc. 1998, 120, 12232-12236.

[29] T. Muraoka, H. Asaji, Y. Yamamoto, I. Matsuda, Chem. Commun. 2000, 199-200.

[30] M. Yamada, R. Ochi, Y. Yamamoto, S. Okada, Y. Maeda, Org. Biomol. Chem. 2017, 15, 8499-8503.

[31] M. Yamada, A. Ishitsuka, Y. Maeda, M. Suzuki, H. Sato, Org. Lett. 2020, 22, 3633-3636.

[32] S.-P. Jiang, W.-Q. Lu, Z. Liu, G.-W. Wang, J. Org. Chem. 2018, 83, 1959-1968.

[33] G. Chen, X. Jiang, C. Fu, S. Ma, Chem. Lett. 2010, 39, 78-81.

[34] B. Alcaide, P. Almendros, C. Aragoncillo, Chem. Soc. Rev. 2014, 43, 3106-3135.

[35] X. Jiang, X. Cheng, S. Ma, Angew. Chem. Int. Ed. 2006, 45, 8009-8013; Angew. Chem. 2006, 118, 8177-8181.

[36] Y.-N. Lim, H.-T. Kim, H.-S. Yoon, H.-Y. Jang, Bull. Korean Chem. Soc. 2011, 32, 3117-3119.

[37] S. M. Kim, J. H. Park, Y. K. Kang, Y. K. Chung, Angew. Chem. Int. Ed. 2009, 48, 4532-4535; Angew. Chem. 2009, 121, 4602-4605.

[38] P. Lu, S. Ma, Org. Lett. 2007, 9, 2095-2097.

[39] T. Kawamura, F. Inagaki, S. Narita, Y. Takahashi, S. Hirata, S. Kitagaki, C. Mukai, Chem. Eur. J. 2010, 16, 5173-5183.

[40] A. Artigas, J. Vila, A. Lledó, M. Solà, A. Pla-Quintana, A. Roglans, Org. Lett. 2019, 21, 6608-6613.

[41] W. Q. Zhai, R. F. Peng, B. Jin, G. W. Wang, Org. Lett. 2014, 16, 1638-1641.

[42] V. Rajeshkumar, F.-W. Chan, S.-C. Chuang, Adv. Synth. Catal. 2012, 354, 2473-2483.

[43] T.-X. Liu, Z. Zhang, Q. Liu, P. Zhang, P. Jia, Z. Zhang, G. Zhang, Org. Lett. 2014, 16, 1020-1023.

[44] A. F. Khlebnikov, M. S. Novikov, M. V. Golovkina, P. P. Petrovskii, A. S. Konev, D. S. Yufit, H. Stoeckli-Evans, Org. Biomol. Chem. 2011, 9, 3886-3895.

[45] M. Hatzimarinaki, M. Orfanopoulos, Org. Lett. 2006, 8, $1775-1778$

[46] W.-Q. Zhai, S.-P. Jiang, R.-F. Peng, B. Jin, G.-W. Wang, Org. Lett. 2015, 17, 1862-1865.
[47] Y.-T. Su, Y.-L. Wang, G.-W. Wang, Org. Chem. Front. 2014, 1, 689-693.

[48] G.-F. Zha, K. P. Rakesh, H. M. Manukumar, C. S. Shantharam, S. Long, Eur. J. Med. Chem. 2019, 162, 465-494.

[49] K. Kordatos, T. Da Ros, M. Prato, V. B. Bensasson, S. Leach, Chem. Phys. 2003, 293, 263-280.

[50] J. C. Hummeler, F. Wudl, M. Prato, J. Am. Chem. Soc. 1995, 117, 7003-7004.

[51] H. Hachiya, Y. Kabe, Chem. Lett. 2009, 38, 372-373.

[52] H. Inoue, H. Yamaguchi, S. Iwamatsu, T. Uozaki, T. Suzuki, T. Akasaka, S. Nagase, S. Murata, Tetrahedron Lett. 2001, 42, 895-897.

[53] X. Zhang, A. Romero, C. S. Foote, J. Am. Chem. Soc. 1993, 115, 11024-11025.

[54] X. Zhang, A. Fan, C. S. Foote, J. Org. Chem. 1996, 61, $5456-5461$.

[55] X. Zhang, C. S. Foote, J. Am. Chem. Soc. 1995, 117, $4271-4275$.

[56] Y. Murata, K. Komatsu, Chem. Lett. 2001, 30, 896-897.

[57] Y. Hashikawa, Y. Murata, ChemPlusChem 2018, 83, 1179-1183.

[58] M. D. Tzirakis, M. Orfanopoulos, Chem. Rev. 2013, 113, 5262-5321.

[59] A data-set collection of computational results is available in the ioChem-BD repository and can be accessed via https://doi.org/10.19061/iochem-bd-4-24. M. ÁlvarezMoreno, C. de Graaf, N. López, F. Maseras, J. M. Poblet, C. Bo, J. Chem. Inf. Model. 2015, 55, 95-103.

[60] J. Mestres, M. Duran, M. Solà, J. Phys. Chem. 1996, 100, 7449-7454.

[61] A. Herrmann, F. Diederich, C. Thilgen, H.-U. Ter Meer, W. H. Müller, Helv. Chim. Acta 1994, 77, 1689-1706.

[62] X.-F. Gao, C.-X. Cui, Y.-J. Liu, J. Phys. Org. Chem. 2012, 25, 850-855.

[63] P. Seiler, A. Herrmann, F. Diederich, Helv. Chim. Acta 1995, 78, 344-354.

[64] F. M. Bickelhaupt, K. N. Houk, Angew. Chem. Int. Ed. 2017, 56, 10070-10086; Angew. Chem. 2017, 129, 10204-10221.

[65] C. S. Wannere, A. Paul, R. Herges, K. N. Houk, H. F. Schaefer III, P. V. R. Schleyer, J. Comput. Chem. 2007, 28, 344-361.

[66] B. J. Levandowski, T. A. Hamlin, R. C. Helgeson, F. M. Bickelhaupt, K. N. Houk, J. Org. Chem. 2018, 83, 31643170.

[67] B. J. Levandowski, D. Svatunek, B. Sohr, H. Mikula, K. N. Houk, J. Am. Chem. Soc. 2019, 141, 2224-2227.

[68] R. Pino-Rios, D. Inostroza, G. Cárdenas-Jirón, W. Tiznado, J. Phys. Chem. A 2019, 123, 10556-10562.

[69] G. Zhan, M. L. Shi, Q. He, W. Du, Y. C. Chen, Org. Lett. 2015, 17, 4750-4753.

[70] O. Fernandez-Delgado, E. Castro, C. R. Ganivet, K Fosnacht, F. Liu, T. Mates, Y. Liu, X. Wu, L. Echegoyen, ACS Appl. Mater. Interfaces 2019, 11, 34408-34415. 